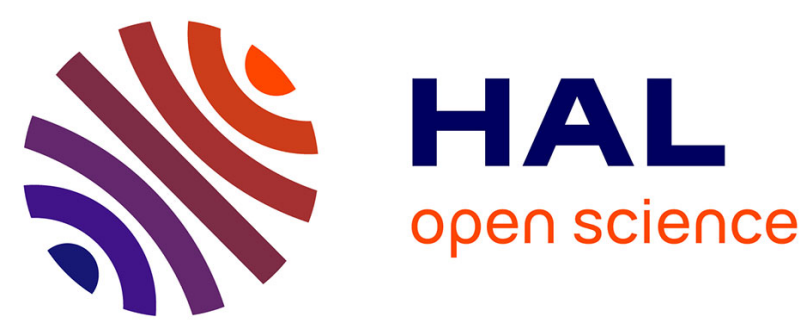

\title{
Recent spatial and temporal changes in the stress regime along the southern Tunisian Atlas front and the Gulf of Gabes: New insights from fault kinematics analysis and seismic profiles
}

Mohamed Gharbi, Olivier Bellier, Amara Masrouhi, Nicolas Espurt

\section{To cite this version:}

Mohamed Gharbi, Olivier Bellier, Amara Masrouhi, Nicolas Espurt. Recent spatial and temporal changes in the stress regime along the southern Tunisian Atlas front and the Gulf of Gabes: New insights from fault kinematics analysis and seismic profiles. Tectonophysics, 2014, 626, pp.120-136. 10.1016/j.tecto.2014.04.003 . hal-01837191

\section{HAL Id: hal-01837191 \\ https://hal.science/hal-01837191}

Submitted on 12 Jul 2018

HAL is a multi-disciplinary open access archive for the deposit and dissemination of scientific research documents, whether they are published or not. The documents may come from teaching and research institutions in France or abroad, or from public or private research centers.
L'archive ouverte pluridisciplinaire $\mathbf{H A L}$, est destinée au dépôt et à la diffusion de documents scientifiques de niveau recherche, publiés ou non, émanant des établissements d'enseignement et de recherche français ou étrangers, des laboratoires publics ou privés. 


\section{Accepted Manuscript}

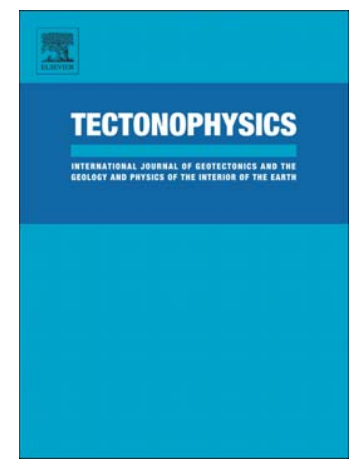

Recent spatial and temporal changes in the stress regime along the southern Tunisian Atlas front and the Gulf of Gabes: New insights from fault kinematics analysis and seismic profiles

Mohamed Gharbi, Olivier Bellier, Amara Masrouhi, Nicolas Espurt

PII: $\quad$ S0040-1951(14)00171-1

DOI: $\quad$ doi: $10.1016 /$ j.tecto.2014.04.003

Reference: $\quad$ TECTO 126256

To appear in: $\quad$ Tectonophysics

Received date: $\quad 8$ May 2013

Revised date: $\quad 28$ March 2014

Accepted date: $\quad 5$ April 2014

Please cite this article as: Gharbi, Mohamed, Bellier, Olivier, Masrouhi, Amara, Espurt, Nicolas, Recent spatial and temporal changes in the stress regime along the southern Tunisian Atlas front and the Gulf of Gabes: New insights from fault kinematics analysis and seismic profiles, Tectonophysics (2014), doi: 10.1016/j.tecto.2014.04.003

This is a PDF file of an unedited manuscript that has been accepted for publication. As a service to our customers we are providing this early version of the manuscript. The manuscript will undergo copyediting, typesetting, and review of the resulting proof before it is published in its final form. Please note that during the production process errors may be discovered which could affect the content, and all legal disclaimers that apply to the journal pertain. 
Recent spatial and temporal changes in the stress regime along the southern Tunisian Atlas front and the Gulf of Gabes: New insights from fault kinematics analysis and seismic profiles.

Mohamed Gharbi ${ }^{\mathrm{a}, \mathrm{b}^{*}}$, Olivier Bellier ${ }^{\mathrm{a}}$, Amara Masrouhi ${ }^{\mathrm{a}, \mathrm{b}}$, Nicolas Espurt $^{\mathrm{a}}$

a Aix-Marseille Université, CNRS, IRD, CEREGE UM34, 13545 Aix-en-Provence, France.

${ }^{b}$ Geo-resources Laboratory, Centre de Recherches et des technologies des Eaux de Borj Cedria, B.P. 273, Soliman 8020, Tunisia

*Corresponding author, gharbim.mohamed@gmail.com

\section{Abstract}

Tectonic deformations in the Southern Atlassic Front of Tunisia (SAFT) and the Gulf of Gabes result from the Nubia-Eurasia convergence. This study, based on the inversion of geologically determined fault slip vectors, presents evidences for spatial and temporal changes in the stress state. Fault kinematics analyses reveal a temporal change in states of stress during the late Cenozoic. A paleostress (Miocene-Pliocene) state is characterized by a regional compressional tectonic regime with a mean $\mathrm{N} 134 \pm 09^{\circ} \mathrm{E}$ trending horizontal maximum stress axis $\left(\sigma_{1}\right)$. A modern (Quaternary to present-day) state of stress also corresponds to compressional tectonic regime with a regionally mean $\mathrm{N} 05 \pm 10^{\circ} \mathrm{E}$ trending horizontal $\sigma_{1}$. The SAFT corresponds to two distinct domains: a far-foreland Atlassic front related to contractional deformation associated with southward propagate thrusting, and eastward, the Gulf of Gabes characterized by normal component NW to WNW trending faults at the crustal margin scale probably related with a transtensional tectonic regime. We propose that the spatial and temporal changes in the stress during the Miocene-Pliocene and Quaternary may result from the geodynamic evolution of the Tunisian Atlas in relation to the rotation of Corsica-Sardinia blocks and the separation of the Sicilian continental lithosphere from the Ionian oceanic lithosphere. These temporal and spatial stress changes along the SAFT and the Gulf of Gabes are probably the engine behind the moderate seismicity, leading at the same time to a reactivation of the inherited major structures created during the evolution of the Southern Tethyan margin.

Keywords: Fault analysis, Seismic data, Stress change, Southern Atlas, Tunisia

\section{Introduction}

The convergence between Nubia and Eurasia causes deformation across the entire Mediterranean domain (Tapponnier, 1977; Le Pichon et al., 1988; Dewey et al. 1989; Sébrier et al., 2006). The Tunisian Atlas constitutes the eastern onshore termination of the Atlassic orogenic belt of North Africa, recording the tectonic history of the western Mediterranean (Caire, 1970; Zargouni, 1984; Dercourt et al., 1986; Zouari et al., 1990; Roure et al. 2012). The geodynamic history of the Tunisian Atlas is divided into two major periods: the first one corresponds to the rifting stage dominated by an extensional tectonic regime in relation with normal faulting that produces a variable sediment 
thickness and distribution of facies during Mesozoic times (Piqué et al., 2002; Guiraud et al., 2005, Gharbi et al., 2013). In contrast during Cenozoic-Quaternary period, the collision of Nubia and Europe induced a compressional tectonic regime characterized by folds combined with reverse and strike slip faults (Gomez et al., 1998; Bouaziz et al., 2002; Piqué et al., 2002; Laville et al., 2007; Frizon de Lamotte et al., 2000; 2009).

Currently, in the western-central part of the Mediterranean Sea, the Tunisian Atlas segment collides with the Corsica-Sardinia tectonic block to the north with a tectonic convergence rate of $\sim 5-8 \mathrm{~mm} / \mathrm{yr}$ (DeMets et al., 1994; Michard et al., 2002; Faccenna et al., 2004; Serpelloni et al., 2007; Billi et al., 2011). This kinematic context generates a major tectonic regime change, leading to compressional tectonic regime in the Tunisian Atlassic domain and extensional tectonic regime in the Pelagian Sea (Fig. 1). The interaction between these two contrasting regimes would be the consequence of the collision between the African and the European plates associated with major temporal and spatial changes in the stress field during Cenozoic. Even though, over the last four decades, many studies carried out in the Southern Atlassic Front of Tunisia (SAFT) and the Gulf of Gabes have documented the structural and geodynamic framework of the Cenozoic deformation (Zargouni and Trémolières, 1981; Zargouni and Ruhland, 1981; Haller, 1983; Hfaiedh, 1983; Ellouz, 1984; Zouari et al., 1990; Bédir et al., 1992; Dlala and Hfaiedh, 1993; Patriat et al., 2003; Catalano et al., 2008; 2009; Frizon de Lamotte et al., 2000; 2011). On the contrary, the Cenozoic fault kinematics and stress regime history in the SAFT and Gulf of Gabes domains, are still poorly documented (Zargouni and Trémolières, 1981; Zouari et al., 1990; Dlala, 1992; Chihi et al., 1992; Bouaziz et al., 2002).

This paper aims to identify stress states evolution during the Miocene-Pliocene and Quaternary periods in the SAFT and the Gulf of Gabes. We focused this study on two specific issues: (1) the identification of a temporal change of the Miocene-Pliocene and Quaternary stress regime in the SAFT by fault kinematics analyses (chronology determination and inversion of slip vectors (striae) measured on fault planes); and (2) the characterization of a spatial change of the Quaternary stress field acting through the wide domain covering from the SAFT to the Gulf of Gabes by fault kinematics analyses and geophysical data.

\section{Tectonic setting}

The study area is located in the eastern part of the western Mediterranean Sea at the eastern edge of the Atlas (Fig. 1). It is divided into two distinct domains in terms of structural style: the SAFT and the Gulf of Gabes. The SAFT is mainly made of S-vergent NE to ENE trending "en echelon" thrust related anticlines (e.g., Jebels Hachichina, Beidha, Berda, Zemlet el Beidha, Orbata and Chemsi) bounded by NW trending lateral ramps (e.g., Gafsa fault system; Said et al., 2011a) (Fig. 2). Eastward, the Gulf of Gabes corresponds to the south-eastern side of the present margin of the Pelagian Sea

(Fig.1). Southeastward the Gulf of Gabes is connected to the Sirt Basin and Jeffara domain. 
Northeastward, it is bounded by the Pantelleria Graben (Fig. 1). This area is characterized by NW trending transtensional and transpressional deep-seated faults, parallel to the Gafsa fault system (Figs. 1 and 2A) (Hfaiedh et al., 1985; Touati and Rodgers, 1998; Chihi et al., 2000; Bédir et al., 2001; Sebei et al., 2007; Boussiga, 2008; Catalano et al., 2008; Taktak et al., 2012). Subsurface data in the Pelagian block area (Haller, 1983; Ellouz, 1984; Bédir et al., 1992) provide evidence for an extensional tectonic regime combined with right lateral strike-slip faults. This extensional strain is associated with graben and half-graben structures (Bédir et al., 1996; Bédir et al., 2001; Taktak et al., 2010).

The timing of the Cenozoic compressional events of the SAFT and the Gulf of Gabes are not yet well established. The Mesozoic extension switched to N-S contraction in the late Cretaceous-early Paleocene during the closing of the Tethys Ocean related with the convergence between Africa and Eurasia (Ben Ferjani et al., 1990; Zouari et al., 1990; Frizon de Lamotte et al., 2000; Bédir et al., 2001; Bouaziz et al., 2002; Guiraud et al., 2005; Said et al., 2011b; Gharbi et al., 2013). Following this first period of contraction, two major compressional events are evidenced in Tunisia: the Atlassic and the Alpine events (Bouaziz et al., 2002; Masrouhi et al., 2008). The Atlassic compressional tectonic event is characterized by a WNW-ESE to NW-SE shortening. It caused the inversion of the major extensional Cretaceous structures in the Eocene (Bouaziz et al., 2002; Bracène and Frizon de Lamotte, 2002; Frizon de Lamotte et al, 2011; Masrouhi and Koyi, 2012; Gharbi et al., 2013; Masrouhi et al., 2013). The second major event corresponds to the paroxysmal Miocene (Tortonian) Alpine event characterized by a regional scale NW to NNW trending compression (Zargouni and Trémolières, 1981; Dlala, 1992; Chihi, 1992; Bouaziz et al., 2002). This compression is responsible for the formation of NE trending folds and thrusts. To sum up, the SAFT is characterized by a compressional stress regime while the Gulf of Gabes is dominated by normal faulting.

\section{Methodology: fault kinematics analysis, inversion method and data separation}

The kinematics of a fault population are defined using the striations (or striae) measured on the fault planes at several sites. The main objective is to define the Mio-Pliocene to present-day states of stress in SE Tunisia and their probable significance in relation to regional tectonic events. The methodology of fault kinematic studies to determine paleostress fields and demonstrate temporal and spatial changes in late Cenozoic stress states has been used in active tectonic areas around the world over the past forty years (e.g., Bellier et al., 1997; Siame et al., 2009; Shabanian et al., 2010; Lacombe et al., 2001; Mercier et al., 2013). The fault kinematic measurements were numerically processed to analyze the fault population data in term of a stress state related to a tectonic regime. In this study we used the inversion method initially proposed by Carey (Carey and Brunier, 1974; Carey, 1979). The fault kinematics inversion method computes a mean best fitting reduced stress tensor (for the definition of reduced stress tensor see for example Lacombe, 2012) from a set of striated faults by minimizing the angular deviation (misfit angle) between a predicted slip vector and 
the observed striations. Inversion methods assume that the slip represented by the striation occurs in the direction of the resolved shear (Bott, 1959; Wallace, 1951).

The inversion results include the orientation (azimuth and plunge) of the principal stress axes $\left(\sigma_{1}>\sigma_{2}>\sigma_{3}\right.$, corresponding to maximum (compressional), intermediate and minimum (extensional) stress axis, respectively) of a mean stress tensor as well as a "stress ratio" $R=\left(\sigma_{2}-\sigma_{1}\right) /\left(\sigma_{3}-\sigma_{1}\right)$; the stress ratio, $R$, of the stress tensor being a linear quantity describing relative stress magnitudes (Carey and Brunier, 1974; Carey-Gailhardis and Mercier, 1987; Mercier et al., 1991; Villemin et al., 1994; Bellier and Zoback, 1995; Lacombe et al., 2001). This parameter (R) is equal to 1- $\phi$, $\phi$ being another commonly used stress ratio (e.g., Angelier, 1979; Lacombe, 2012). As defined, it varies between two end-member uniaxial stress states $\left(R=0\right.$ when $\sigma_{2}=\sigma_{1}$ and $R=1$ when $\sigma_{2}=\sigma_{3}$, e.g., Carey and Brunier, 1974; Mercier et al., 1991). The significance of stress-ratio in interpreting inversion results was already discussed by previous authors (e.g., Bellier and Zoback, 1995; Shabanian et al., 2010, and references therein).

In our study, the fault kinematics data have been measured in late Cretaceous to Quaternary age deposits (Table. 1). In this paper we present selected data related with the more recent faulting episodes, majorly emplaced after the main folding (e.g., Gharbi, 2013). Pre-tilting fault system evolution will be presented in an other paper related to the fault and folding evolution. Among the total twenty-one inspected outcrops (measurement sites in Fig. 2B) only three sites were measured in Cretaceous formations which in turn are cut by major faults that were produced or reactivated during post-Miocene tectonic events. The majority of the striated fault planes were measured along or in the vicinity of fault zones affecting the Late Cenozoic (Late Miocene to Quaternary) deposits (Table. 1). Slip vector (striae) measurements were done on minor (decimeter scale), major (several tens meters scale) fault planes, as well as on pebble face planes of Segui formation (Plio-quaternary, age from Mannaï-Tayech, 2009) or Quaternary terraces conglomerates.

Often, the observed fault planes have more than one set of striae (Fig. 3). These distinct datasets are separated using structural arguments such as the relative striae cross-cutting relationships (Figs. 3.a, b). Detected relative chronology between striae and their relationship are reliable to the known tectonic events (more detail in methodology see Bellier and Zoback, 1995; Lacombe et al., 2006; Shabanian et al., 2010; Hippolyte et al., 2012; Lacombe, 2012; Célérier et al., 2012). We report in the Fig. 3.c fault planes which contain superimposed slip-vectors measured at several sites and thus their relative chronologies. We detected two slip generations of striations revealed by clear cross-cutting striation on fault planes in the most of measured sites. 


\section{Late Cenozoic fault kinematics in the Southern Atlassic Front of Tunisia (Late Miocene to Present-day) and the Gulf of Gabes}

\subsection{Fault kinematics and stress regimes in the Southern Atlassic domain}

Fault slip chronologies and inversions of the slip-vectors indicate strike-slip, and reverse faulting that correspond to regionally and/or locally significant stress regimes along the SAFT (site location in Fig. 2B). The data reported in this study provide evidence for strike-slip and reverse faulting affecting mainly Miocene-Pliocene and Quaternary deposits.

Following the methodology explained in section 2, the separation of fault kinematics data (Table. 1) allows to identify two distinct slip generations (Figs. 4, 5 and 6) defining two successive stress states of compression which changes from a Miocene-Pliocene (i.e. paleostress) to Quaternary to presentday (i.e. modern stress) stress states in the SAFT. The change occurs probably at the end of the Pliocene or the beginning of the Quaternary (see below).

\subsubsection{Oldest faulting event and related paleostress regime}

To determine the paleostress state in the SAFT, the inversion of fault slip data are individually applied on the fault populations including the oldest fault kinematics and other compatible fault planes measured at the same sites. The computed stress tensors belong to the oldest stress state of the SAFT deformation domain reveals a homogenous stress field (Figs 4, 6a and Table.1). The direction of the horizontal maximum principal stress axes $\left(\sigma_{\mathrm{hmax}}=\sigma_{1}\right)$ of these paleostress solutions are presented in Figure 6a. The computed paleostress states of the seventeen sites show a regional pattern of $\mathrm{N} 134 \pm 09^{\circ} \mathrm{E}$ trending horizontal compression deduced from the average value calculated from the individual axes (mean $\sigma_{1}$, Fig. 6a). This compression appears significantly homogenous across the entire region including the Orbata and Chemsi anticlines (Fig. 2). The stress tensors calculated from data of almost all the studied sites show a purely compressional stress regime compatible with the kinematic regime of the SAFT structures. Locally sites 11 and 86 (Fig. 4) indicate local strike slip stress states. However, in both cases the high value of the stress ratio indicates a local transpressional (close to compressional) tectonic regime, agreeing with the regional compressional tectonic regime. Faulting is consequently consistent with a compressional stress regime responsible for the reverse movement, leading to the SAFT thrusting. Most of the analysed thrusting is postdating the main folding because of several fault set inversions provide horizontal compressional stress axes from faults affecting tilted formations. In fact, the NW trending paleostress compression is compatible with a minor right-lateral component of slip along the $E$ trending major thrusts.

\subsubsection{Recent faulting event and related modern stress regime}

The recent (modern) tensors derived from fault-slip data indicate a dominantly compressional stress regime involving both strike-slip and reverse faults affecting the Mio-Pliocene and the Quaternary terraces. 
The computed stress tensors belong to the modern stress state of the SAFT deformation domain reveals a relatively homogenous stress field (Figs. 5, 6a and Table. 1). The direction of the horizontal maximum principal stress axes $\left(\sigma_{\mathrm{hmax}}=\sigma_{1}\right)$ of these inversion solutions are presented in Figure $6 \mathrm{a}$. This compressional regional stress regime throughout the study area is clearly observed all along-strike the ENE trending reverse faults of Orbata and Chemsi anticlines. Thus, it is well distributed along the Atlassic system of Tunisia.

The recent stress field was deduced from the youngest fault kinematics data observed at individual studied sites where the majority of fault slip data was measured in Miocene-Pliocene conglomerates. Almost all of the computed stress tensors determined geologically from fault slip measurements harvested along the front of Orbata and Chemsi anticlines represent a relatively homogenous stress regime though a wide region (Fig. $6 \mathrm{~b}$ and Table. 1); this modern stress field being characterized by a mean $\mathrm{N} 05 \pm 10^{\circ} \mathrm{E}$ trending horizontal $\sigma_{1}$ (average value deduced from the individual site axes). Only one site of kinematic measurement along the Jebel Orbata front (S281, Figs. 5 and 6b) provides a local NE trending $\sigma_{1}$ compressional state of stress. It could be due to stress perturbations probably related to the presence of pre-existing discontinuities that have been modelled by Homberg et al. (1997) for example (see discussion).

As mentioned above, the aim of this paper is to characterize the recent stress orientation along the SAFT. To obtain the relevant data for testifying of the more recent tectonic regime, field studies have been carried out in Quaternary terraces in the front of the Orbata and Chemsi anticlines (stereonet in Fig. 7, site location Fig. 2B).

The first example is site 91A (stereonet 91AQ on Fig. 7), located along the front of the Chemsi anticline. At this locality, the Chemsi front is characterized by a surficial back-thrust deforming the Miocene-Pliocene deposits and a Quaternary terrace (Fig. 8 a, b and c). Slip measurements at site 91AQ correspond to striations on faults planes affecting nearly horizontal to weakly tilted Quaternary terrace. The stereoplot of this site shows transpressional stress regime with a $\mathrm{N} 181^{\circ} \mathrm{E}$ trending $\sigma_{1}$ and $\mathrm{N} 87^{\circ} \mathrm{E}$ trending $\sigma_{3}$, as shown in Figure 7 . However, this solution is poorly constrained, only $\sigma_{1}$ is well determined and closely consistent with the regional (mean) compression axis reported on Figure 6b. The second example is site $\mathrm{O} 24 \mathrm{Q}$, located $500 \mathrm{~m}$ of the site $91 \mathrm{AQ}$ along the front of the Chemsi anticline (Fig. 2). Measurements have been done in nearly horizontal Quaternary terrace beds. The fault kinematics data set yields a strike-slip stress state characterized by a $\mathrm{N} 22^{\circ} \mathrm{E}$ trending $\sigma_{1}$ and $\mathrm{N} 268^{\circ} \mathrm{E}$ trending $\sigma_{3}$ (Fig. 7), therefore the striation inversion in the Quaternary terraces yields a result indicating locally a youngest transpressional stress regime. However, the stress ratio high value indicates a local stress state close to compressional one of which the $\sigma_{1}$ horizontal strike is closely consistent with the compression of the modern regional compressional tectonic regime (Fig. 6b). 
The third example (site S281Q) corresponds to measurements in the Quaternary terrace in the Jebel Orbata (location on Fig. 2). The deduced recent stress state is a compressional stress regime $\left(\sigma_{v}=\sigma_{3}\right)$ characterized by a calculated $\mathrm{N} 200^{\circ} \mathrm{E}$ trending $\sigma_{1}$ (Fig. 7) relatively consistent with mean regional compression related to the modern compressional stress state. Calculated $\sigma_{1}$ being in the bedding plane (dashed red plane in S281Q, Fig. 7), this suggest that part of the faulting (fault slip) was developed during the tilting (this could explain the bad distribution of the measured and calculated slip vector angles, e.g., Angelier, 1979; Bellier and Zoback, 1995; Lacombe, 2012).

At Orbata and Chemsi localities, brittle deformation regionally shows reverse oblique-slip faulting that agree with approximately $\mathrm{N}$ trending compression. The inversions yield compressional stress states $\left(\sigma_{v}=\sigma_{3}\right.$ ), while locally we observed strike-slip faulting (site 101, in Figs. 5, 6). This last one, like results from measurements in Quaternary terraces in sites 91A, 024 (see above) corresponds to local transpressional stress states compatible with the kinematic regime of the front of fold structures because they are closely consistent (in $\sigma_{1}$ direction) with the regional compressional regime. These local stress states, like the clockwise rotation of $\sigma_{1}$ in site 101 , could result from deformation heterogeneities and/or stress perturbations probably related to the presence of pre-existing discontinuities (e.g., Homberg et al., 1997).

The majority of the analyzed striated fault planes indicate that the dominant stress regime in the SAFT corresponds to a regional compressional regime. The recent stress fields, deduced from the youngest fault kinematics data, reveal a quaternary tectonic activity along the foreland of Atlassic structures that generate recent thrust reactivation like the Chemsi back-thrust (Fig. 8).

\subsection{Stress field in SE Tunisia}

Following the methodology exposed in section 2 and applied in section 3.1, our study allowed to observe in Koudiat Hammamet, close to the Gabes Gulf, one site of fault slip measurements (site A31, localized in Fig. 2) where two drastically different fault kinematics, have been measured in Quaternary deposits. This fault kinematic analysis (site A31, Fig.9) and Table. 1) indicates strike-slip and normal faulting corresponding to local successive stress states. (1) The first kinematics corresponds to a strike-slip component faulting consistent with a transpressional stress regime (site A331 in Fig 9) of which the NNW trending $\sigma_{1}$ axis is consistent with the compressional stress states in the southern Atlassic front. (2) The recent kinematics testified for an extensional (normal faulting) tectonic regime characterizes an ENE trending minimum stress axis ( $\sigma_{3}$; sites A332 in Fig. 9). This local youngest extensional stress regime is consistent with the normal component faulting within the Gulf of Gabes. A similar extensional tectonic regime has been displayed at several sites in the coastal area of southern Tunisia (Bouaziz et al., 2003), it can result from local kinematics in relation with a transtensional tectonic regime acting in the Pelagian domain. 


\subsection{Seismotectonic data}

In the Tunisian Atlas, the seismicity is concentrated in a narrow belt along the northern of Tunisia, SAFT, coastal block and the Pelagian Sea. Instrumental seismicity indicates that the onshore and offshore areas of Tunisia are still active, especially along the major oblique fault systems (Fig. 10, Table. 2). Earthquakes have generally moderate magnitude $(<5.3$, Table. 2$)$ and focal mechanisms do not outline a rather simple deformation pattern. Unfortunately, the available data set (Table. 2) is clearly insufficient to carry out a stress inversion analysis. However we can extract a general trend from west to east.

In and around the Tunisian Atlas (western part) the focal mechanisms correspond to reverse and strike-slip faulting in agreement with an intermediate stress regime between compressional and transpressional, (Fig. 10) compatible with a NNW trending compression axis. This is clearly consistent with the high value of several stress ratio of the fault kinematics analyses in the SAFT domain (section 3.1) that indicate a regional compressional tectonic regime close to transpressional. In the detail, P axis strikes change from NW-SE (i.e. Gafsa and Chott range, Fig. 10) to E-W (i.e. coastal block, Fig. 9). This can be associated with tendency change in the activity of the Tunisian belt (Gueddiche, 1992; Rebaï et al., 1992; Dlala and Hfaiedh, 1993; Dlala and Rebaï, 1994). In the southernmost Atlas of Tunisia, the NW trending $\sigma_{1}$ compressional tectonic regime deducible from the earthquake focal mechanisms can correspond to recent reactivation of blind thrust front (Vially et al., 1994).

In the Pelagian Sea domain (eastern part) focal mechanisms mainly indicate strike-slip faulting of which the $\mathrm{P}$ axis strikes are consistent with a NW to NNW trending compressional stress axes in agreement with the predicted Nubia-Eurasia plate motion (Serpelloni et al., 2007). This active tectonic regime derived from the focal mechanisms agrees with a right-lateral component motion along a pre-existing NW striking fault system. These observations can be reconciled with a recent strike-slip reactivation of the pre-existing normal faults inherited from the Cretaceous rifting. In conclusion, in the offshore Pelagian block, the moderate seismicity displays a strike-slip tectonic regime with $\mathrm{P}$ and $\mathrm{T}$ axes striking NW-SE and NE-SW (Fig. 9) respectively, in agreement with other seismological and geophysical data.

\section{Structural evidence for recent faulting onshore and offshore of Tunisia}

\subsection{Structural evidence for present-day faulting in the SAFT}

Late Cenozoic tectonics in the Atlassic domain of Tunisia is characterized by reverse, and strike-slip faulting related to the reactivation of inherited Mesozoic structures. Fault slip data collected along both major and minor faults in Orbata, Chemsi and Koudiat Hammamet anticlines suggest a temporal and spatial changes in the stress regimes from the Miocene-Pliocene to Quaternary. During the Quaternary period, the study area is structurally very complex because characterized by (1) a recent 
compressional stress regime responsible for folding and still active thrusting in the Atlas domain, and (2) a normal faulting component tectonic regime southeast-ward in the Gulf of Gabes.

In the Orbata anticline, a key outcrop was investigated west of Jebel Hamadi (site 101; Figs. 2B and $8 \mathrm{~A})$ providing geological evidence of the present-day tectonics. In that location, the ENE trending Orbata anticline exposes $45-50^{\circ} \mathrm{N}$-dipping overturned southern $\operatorname{limb}$. The $\operatorname{limb}$ is formed by Eocene limestones (Fig. 8A) unconformably overlain by sub-vertical Miocene-Pliocene syn-tectonic conglomerates. The structural analysis of the front of the Orbata anticline shows a recent deformation. These conglomerates are affected by a WNW trending thrust fault (Fig. 8A).

In the southern front of the Chemsi anticline, the stress state deduced from the fault kinematic analysis and the geological mapping have been used to determine the present-day stress orientations. The Chemsi anticline is limited by an ENE trending thrust to the south during the NW trending Miocene-Pliocene compression. In fact the southern limb of this anticline is overturned and dips $45^{\circ} \mathrm{N}$ (Fig. 8B). The surficial back-thrust which develops at the southern front of the Chemsi front and deforms the Miocene-Pliocene conglomerates and a Quaternary terrace provides evidence for its recent reverse faulting reactivation under a compressional tectonic regime (Fig. 8B). In fact, this recent deformation provides kinematic constraints on active faulting in the SAFT that results from a NNE trending compression.

Southward of the SAFT, the detailed geologic mapping of Koudiat Hammamet shows numerous $\mathrm{N} 115^{\circ} \mathrm{E}$ trending strike-slip faults. The Koudiat Hammamet faults affect the Eocene-Miocene deposits with an evidence of recent lateral and normal displacements (Fig. 9). The present-day stress field, as derived from structural analysis, is characterized by a NE trending extensional axis that could be in relation with a regional transtensional regime.

\subsection{Recent normal faulting as revealed by seismic profiles in the southern offshore of Tunisia, in the Gulf of Gabes}

The Gulf of Gabes is part of the Pelagian Block (Fig. 1). This basin has undergone a high subsidence rate during the Mesozoic (Boccalleti et al., 1987; Ben Ferjani et al., 1990; Burollet, 1991; Pateriat et al., 2003). Currently, this area is characterized by $\sim \mathrm{N} 150^{\circ} \mathrm{E}$ trending faults (Marchal et al., 2003) connecting the SE Tunisian compressional domain with the Jeffara platform (Fig. 1). The whole Gulf of Gabes was structured by continuous reactivation of deep-seated major faults. This tectonic pattern is accompanied by the halokinetic activity associated with a synsedimentary normal faulting (Touati and Rodgers, 1998; Patriat et al., 2003). This transitional zone constitutes an interesting area to investigate the kinematics of the extensional processes and their role in the Cenozoic structure evolution. 


\subsubsection{Seismic data}

The study of the Cenozoic tectonic regimes in the Gulf of Gabes is mainly based on interpretation of 2D seismic reflection lines that have been collected and provided by the ETAP Company. The interpretation of the two profiles (L35 and L155) was achieved by using five exploration wells (P1 to P5, Fig. 11) on the basis of previously supersequence interpretation (Touati and Rodgers, 1998; Takatak et al., 2012). Although the wells are located at some hundred meters from the seismic lines, well data have been projected onto the two seismic profiles at structurally similar locations, with respect to the orientation of the structures. This subsurface study aims to determine the tectonic events and to specify the structural evolution of the SE Tunisian domain. It allows to identify major faults and their role in the Cenozoic and Quaternary structural evolution of the Gulf of Gabes and the interaction with the Cenozoic tectonic stress regime identified by the present study in the SAFT.

\subsubsection{Interpretation of seismic reflection data}

The aim of this section is to decipher the tectonic activity during the Cenozoic period in the Gulf of Gabes. Seismic reflection data show that the Gulf of Gabes is affected by deep-seated high-angle normal faults (Marchal et al., 2003). These faults cut though Cretaceous-Quaternary series and delimit horst and graben structures (Fig. 11; Ben Ferjani et al., 1990; Burollet, 1991; Bédir et al., 1992; Bédir et al., 2001; Tlig et al., 2010). The Cretaceous-Cenozoic transition is underlined by a major unconformity with the gap of Paleocene-early Eocene sequences. This sedimentation gap may be explained by uplift and subsequent erosion of the basin related to active Maastrichtian-Paleocene tectonic events (Taktak et al., 2010). Seismic line L35 shows that the late Eocene series, which develop only in the easternmost part of the basin, are affected by normal faulting (Fig. 11; Taktak et al., 2012). The seismic profiles also show normal component faulting and a thickness increase of the Oligocene and Miocene sequences towards the east. It could result from an extensional or transtensional regime. This eastward thickness increase is accompanied by a lateral facies changes and enrichment with a pelagic fauna (Ben Ferjani et al., 1990; Touati and Rodgers, 1998; Mejri et al. 2006; Taktak et al., 2012). During the Miocene, normal component movements permit on the one hand the emplacement of syncline depocenters and, on the other hand, the opening of en echelon half grabens and grabens (Bédir et al., 1992; Touati and Rodgers, 1998). Finally, the seismic profiles show that the Plio-Quaternary series are mainly affected by normal component faults. This normal faulting agrees with a NE trending extension.

To sum up, during the Cenozoic, the Gulf of Gabes has undergone extensional deformation, subsidence and eastward tilting (Ben Ferjani et al., 1990; Touati and Rodgers, 1998; Taktak et al., 2010, 2012). This structural evolution was mainly controlled by the NW trending faults maybe inherited from the Mesozoic rifting (Fig. 11; Burollet and Ellouz, 1986; Ben Ferjani et al., 1990; Taktak 
et al., 2010). In addition seismic data and structural analysis from the Pelagian Sea, presented by recent studies, indicate a recent NW-SE oblique-slip normal faulting that delimits major grabens such as the graben of Zohra (Burollet, 1991; Touati and Rodgers, 1998). The faulting is also consistent with the NE trending tectonic extension stated before (e.g. Catalano et al., 2008; 2009). These aforementioned grabens are the prolongation of the Sirte basin to the south and the Pantelleria rift zone to the north.

However, the combination of the focal mechanism analysis providing evidence for strike-slip faulting (section 3.3) and the seismic section analysis, i.e., geometry and thickness variations of the Late Cenozoic series, providing recent normal faulting component tectonic regime, could be related to a regional transtensional stress regime during the recent period, i.e., Plio-Quaternary, in the Gulf of Gabes. The first order observation of the both analysed profiles (L35 and L155, Fig. 11) display evidence for the long term inherited dominant normal faulting for the fault systems affecting the in the Gulf of Gabes, nevertheless the geometry and distribution of the fault displayed on the section L155, seems like surface flower structures suggesting a potential recent strike-slip faulting reactivation agreeing with our interpretation of the recent emplacement of a regional transtensional stress regime in this transition area between the SAFT and the Pelagian domains.

\section{Interpretation of results and discussion}

\subsection{Temporal and spatial changes from the Mio-Pliocene to Quaternary stress states in the SAFT and the Pelagian Sea domains}

Twenty-one sites of the fault kinematics have been mainly measured in Miocene-Pliocene and Quaternary deposits. Most of the striated fault planes cut the Pliocene conglomerates of the Segui formation. Late Cenozoic stress state reconstructions by means of inversion of fault-slip data display evidence for a temporal change of the stress regime in the SAFT. Indeed, the Miocene-Pliocene to Quaternary deposits record two distinct successive compressional stress states (Fig. 6) named the paleostress (1), and modern (2) stress states. The stress state change clearly occurred in the late Pliocene or in the early Pleistocene because both compressions in the SAFT affected the PlioPleistocene (undifferentiated) Segui formation (Pliocene to Villafranchian age from Mannaï-Tayech, 2009).

(1) The paleostress state characterized by a regional compressional tectonic regime with a mean NW trending horizontal maximum stress axis $\left(\sigma_{1}\right)$ attributed to Late Miocene-Pliocene. It corresponds to the defined Atlassic event reported by several studies in Tunisia (Zargouni, 1984; Tlig et al., 1991; Chihi, 1992; Dlala, 1992), and that has been also named the Alpine event in others studies (Bouillin, 1986; Herkat and Guiraud, 2006; Masrouhi et al., 2007, 2008). (2) The youngest state of stress, i.e. the modern state of stress, also corresponds to a compressional tectonic regime. Some data rather 
support local transpressional tectonic regime, which can be induced by the motion of the strike-slip transfer fault zones of the SAFT. Our data indicate that this recent stress regime is characterized by an about $\mathrm{N}$ trending $\sigma_{1}$. This resulting recent stress fields, deduced from the youngest fault kinematics data in the Mio-Pliocene formations as well as from faulting in Quaternary terraces, reveal the present-day tectonic regime affecting the SAFT; this stress regime might explain the recent tectonic activity along the foreland of Atlassic structures. The Plio-Pleistocene tectonic regime change that we displayed in this study is probably related to the recent tectonic reorganization, at about $2 \mathrm{Ma}$, reported by several authors in the south-central Mediterranean (e.g., Goes et al., 2004; Billi et al., 2011; Nocquet, 2012).

The present-day stress pattern along the SAFT shows also a spatial change in the stress field. Along the SAFT, the youngest stress regime corresponds to $\mathrm{N}$ trending compression which progressively changes eastward to NW to NNW trending horizontal $\sigma_{1}$. At a Tunisian regional scale, few studies (Philip et al., 1986; Chihi et al., 1992) examined these temporal and spatial changes in the stress regime. The recent tectonic regime in Tunisia that can be deduced from inversions of fault-slip data represents a transtensional stress regime along the major Plio-Quaternary trough (Philip et al., 1986; Chihi et al., 1992; Belguith et al., 2011). This tectonic event was reported as a transient event that started after the major compressional event of Late Miocene age. The Plio-Quaternary transtensional tectonic regime is well defined in the Sahel of Tunisia and along the eastern Tunisian coast (Bouaziz et al., 2003; Ghribi and Bouaziz, 2010; Belguith et al., 2011). This area is bordered to the west by the NW trending Atlassic fold and to the South by the stable Saharan platform marked by NW trending fault systems (Bouaziz et al., 2002), while the most active tectonic deformation in the Gulf of Gabes corresponds to the reactivation of pre-existing NW trending normal faults affecting NEto ENE trending $\sigma_{3}$ transtensional stress regime (Fig. 12).

In conclusion, our result synthesis combined with previous studies reveals that the SAFT and the Pelagian Sea are characterized by temporal change in stress regime, which started during Late Cenozoic. Along the SAFT, the youngest stress regime is $\mathrm{N}$ trending compression which progressively changes eastward to a NW trending $\sigma_{1}$ transtensional tectonic regime around the Gulf of Gabes. Indeed, the present-day stress regime along the study area shows also a spatial stress regime change that can be explained by the geodynamic evolution of the Tunisian Atlas in relation to the rotation of Corsica-Sardinia blocks and the separation of the Sicilian continental lithosphere from the Ionian oceanic lithosphere.

\subsection{The regional tectonic regimes in the western Mediterranean}

Southern Tunisia constitutes a complex tectonic zone, which includes two drastically different tectonic domains: the Tunisian Atlas and the Pelagian Sea basin (Figs. 2A and 12). The Late Cenozoic to present-day tectonic regime in the Tunisia is under influence of a combination of the Nubia- 
Europe collision, in the North, and the rifting of the Sicily basin, to the East (Winnock, 1981; Finetti, 1984; Faccenna et al., 2002; Michard et al., 2002; Piqué et al., 2002; Goes et al., 2004; Serpelloni et al., 2007; Kherroubi et al., 2009; Rekhiss, 2008; Billi et al., 2011; Nocquet, 2012; Roure et al., 2012). At the western Mediterranean scale and based on tectonic, seismological, geodetic, tomographic, and seismic reflection data, several geodynamic models have been proposed (e.g., Billi et al., 2011, Belguith et al. 2013). Regionally, the Southern Tunisian Atlas and the Gulf of Gabes were usually examined independently in previous studies (e.g. Zargouni, 1984; Taktak et al., 2012) without any explanation about these coeval but drastically different regimes within closed regions.

In fact, in consequence to the counter clockwise rotation of Corsica-Sardinia blocks that has driven the geodynamics of the Calabrian arc since the late Oligocene-early Miocene. This arc is mainly migrated southeast-ward following the opening of the Tyrrhenian Sea. As concerns the southern Atlas, the compressional regime induced by the Calabrian arc migration through the African plate drift seems to provide the most straightforward explanation for setting up of the thrusting and folding. Presently, this rotation is associated with $\mathrm{N}$ trending compressional stress, associated with recent reactivation of inherited normal faults as major thrusts in the SAFT (Figs. 2, 10 and 12). During the same time, the structural pattern in the Pelagian Sea is controlled by a regional NW trending strike-slip fault (Boccaletti et al., 1987; Gardiner et al., 1995; Torelli et al., 1991; Catalano et al., 1996).

On the contrary, other studies (Finetti and Del Ben, 2005; Torelli et al., 1991) suggest that this region corresponds to a passive margin characterized by a NE trending extension. The structural architecture of this domain remains related to the present-day lithospheric scale continental extension controlled by NW trending normal faults (Finetti and Del Ben, 2005; Torelli et al., 1991). Southward, from the Pelagian Sea, this rifting continued from the Sirte basin to the Gulf of Gabes. The extensional NE trending deformation can be related to the subduction of the NW-moving Ionian oceanic lithosphere accommodating the Nubia-Eurasia convergence.

Unfortunately, in northern Algeria and Tunisia, detailed present-day strain rate field is not available due to the non-existence of dense GPS network. However, some GPS sites along the coast of northern Algeria show that this segment of the Nubia-Eurasia plate boundary accommodates an about NW trending $\sim 2-4 \mathrm{~mm} / \mathrm{yr}$ convergence rate (Serpelloni et al., 2007). Eastward, we note that a $\mathrm{N}-\mathrm{S}$ shortening actively affected the Sardinia channel similarly than in the southern Tyrrhenian basin (Mantovani et al., 2009; Billi et al., 2011; Elter et al., 2011). This drastically heterogeneous structural pattern explains the geodynamic complexity of the study area.

In this regard one should consider that the Tunisian south-eastern offshore is a transient zone passive margin. As a result of this present study, we can support a model that this region could be a microplate guided by an inherited NW trending fault systems acting now as transtensional dextral - 
normal faults during the Plio-Quaternary period. In fact, GPS velocity data and geophysical analysis of the Mediterranean reveals, during Quaternary to present-day, an extensional tectonic regime in the Pelagian Sea, associated with an about ENE trending extension transtensional stress regime (Fig. 12, e.g. Catalano et al., 2008, 2009; Civile et al., 2008; Gallais et al., 2011), but rather that, the compressional tectonic regime is distributed throughout the SAFT is currently (during the PlioQuaternary) accommodated by a predominant $\mathrm{N}$ trending compression under the influence of the Nubia-Eurasia plate convergence.

\section{Conclusions}

This study, based on fault kinematic analysis in the SAFT combined with focal mechanisms of earthquakes affecting SE Tunisia and the interpretations of some seismic profiles in the Gulf of Gabes, provides evidence for spatial and temporal changes in the stress regimes.

The SAFT was affected by a Miocene-Pliocene paleostress field characterized by a regional mean of $\mathrm{N} 134 \pm 09^{\circ} \mathrm{E}$ trending horizontal compression $\left(\sigma_{1}\right)$ and related with a regionally significant compressional tectonic regime.

The Pliocene to present-day modern state of stress corresponds to a compressional tectonic regime with a regional mean of $\mathrm{N} 05 \pm 10^{\circ} \mathrm{E}$ trending horizontal compression $\left(\sigma_{1}\right)$. In fact the present-day regionally significant stress field is varying from a $\mathrm{N}$ trending compression testified by active thrusting in the SAFT to a transtensional tectonic regime in the Gulf of Gabes represented by normal component faulting in the offshore domain.

The change, from Miocene-Pliocene to present-day stress state, occurred in the Pliocene or in the early Pleistocene because both compressions in the SAFT affected the Plio-Pleistocene (undifferentiated) Segui formation. This temporal tectonic regime change is probably related to the recent tectonic reorganization, at about $2 \mathrm{Ma}$, reported in Mediterranean domain (e.g., Goes et al., 2004).

This stress regimes change, documented in this paper, may be attributed to the tectonic blocks position and/or evolution i.e. the Tunisian Atlassic fold-and-thrust belt and the Pelagian Sea relative to the Sardinia and the Mesozoic lonian oceanic lithosphere. The present-day shortening direction in these domains results from combination of the collision between Nubia-Europe and the rifting of the Sicily basin. This structural context is probably explained by the reactivation of the inherited predominant structures created during the evolution of the Southern Tethyan margin. Therefore, the SAFT is mainly made of reactivated of inherited faults and corresponds now to a south-vergent NE to ENE trending "en echelon" thrust-related anticlines. Southeast-ward, major pre-existing normal faults, inherited from the Jurassic-Cretaceous rifting, were recently reactivated by strike-slip component faulting of the Tunisian eastern offshore. Finally, it appears that more investigations of 
the quaternary tectonics elements in this domain can contribute to better constrain the position and/or evolution of the adjacent blocks and the reconstruction of the geodynamics models.

\section{Acknowledgements}

This work gained financial support from the Ministry of Higher Education and Research (Tunisia, especially the University of Gabes) and a Foreign Affair Ministry (Ministère des Affaires Etrangères) grant through French Embassy in Tunisia. Special thanks to Imen Annabi (Responsible of the academic mobility SCAC / IFC in Tunis) and the staff of the SCAC of the French Embassy in Tunisia, for their support. Mohamed Gharbi benefit of funding of Aix-Marseille University through the OT-Med Labex Program (2012-2013) for theirs travels and visits in CEREGE. This work is a contribution to the Labex OT-Med ( $\mathrm{n}^{\circ}$ ANR-11-LABX-0061) funded by the French Government «Investissements $d^{\prime}$ Avenir» program of the French National Research Agency (ANR) through the $A^{*}$ MIDEX project $\left(n^{\circ}\right.$ ANR-11-IDEX-0001-02). Field has benefited from financial support under UPCAM RFQ's International actions. SPOT images were provided thanks to the ISIS program (CNES, distribution SPOT images S.A.). The ETAP (Entreprise Tunisienne des Activités Pétrolières), particularly Abdelhak Amri and Youssef Bouazizi are thanked for providing access to the seismic lines. We are indebted to Olivier Lacombe and François Roure for their thoughtful reviews of the manuscript. We are grateful to Rita Katharina Kraus for comments and English language corrections.

\section{References}

Angelier, J., 1979. Determination of the mean principal directions of stresses for a given fault population. Tectonophysics 56, 17-26.

Bédir, M., Boukadi, N., Tlig, S., Ben Timzal, F., Zitouni, L., Alouani, R., Slimane, F., Bobier, C., Zargouni, F., 2001. Subsurface Mesozoic Basins in the Central Atlas of Tunisia, tectonics, sequence deposit distribution and hydrocarbon potential. AAPG. Bull. 85, 885-907.

Bédir, M., Tlig, S., Bobier, C., Aissaoui, N., 1996. Sequence stratigraphy, basin dynamics and petroleum geology of the Miocene from Eastern Tunisia. AAPG. Bull. 80 (1), 63-81

Bédir, M., Zargouni, F., Tlig, S., Bobier, C., 1992. Subsurface geodynamics and petroleum geology of a transform margin basin in The Sahel of Mahdia and El Jem (Eastern Tunisia). AAPG Bull. 76, 1417-1442.

Belguith, Y., Geoffroy, L., Rigane, A., Gourmelen, C., Ben Dhia, H., 2011. Neogene extensional deformation and related stress regimes in central Tunisia. Tectonophysics. 509, 198-207, doi.org/10.1016/j.tecto.2011.06.009. 
Belguith, Y., Geoffroy, L., Mourgues, R., Rigane, A., 2013. Analogue modelling of Late Miocene-Early Quaternary continental crustal extension in the Tunisia-Sicily Channel area. Tectonophysics. 608, 576-585 doi.org/10.1016/j.tecto.2013.08.023.

Bellier, O., Over, S., Poisson, A., Andrieux, J., 1997. Recent temporal change in the stress state and modern stress field along North Anatolian Fault Zone (Turkey). Geophys. J. Int. 131, 61-86.

Bellier, O., Zoback, M.L., 1995. Recent state of stress change in the Walker Lane zone, western Basin and Range province, United States. Tectonics 14, 564-593.

Ben Ferjani, A., Burollet, P.F., Mejri, F., 1990. Petroleum geology of Tunisia. Mém. ETAP Memoir 1, Tunis, Tunisia, $194 \mathrm{pp}$.

Ben Haj Ali, M., Jedoui, Y., Dali, T., Ben Salem, H., Memmi, L., 1985. Carte géologique de la Tunisie au 1/500 000. Edt. Service Géologique. Office National des Mines.

Billi, A., Faccenna, C., Bellier, O., Minelli, L., Neri, G., Piromallo, C., Presti, D., Scrocca, D., Serpelloni, E., 2011. Recent tectonic reorganization of the Nubia-Eurasia convergent boundary heading for the closure of the western Mediterranean. Bull. Soc. Geol. Fr. 182, 279-303.

Boccaletti, M., Cello G. \& Tortorici, L., 1987. Transtensional tectonics in the Sicily Channel. J. Struct. Geol. 9, 869-876.

Bott, M. H. P., 1959. The mechanism of oblique slip faulting, Geol. Mag., 96, 109-117.

Bouaziz, S., Barrier, E., Soussi, M., Turki, M.M., Zouari, H., 2002. Tectonic evolution of the northern African margin in Tunisia from paleostress data and sedimentary record. Tectonophysics 357, 227-253.

Bouaziz, S., Jedoui, Y., Barrier, E., Angelier, J., 2003. Neotectonics in the Tyrrhenian marine deposits of the southeastern Tunisian coast: implications for sea level changes. C. R. Geoscience 335, 247-254

Bouillin, J. P., 1986. Le bassin maghrébin, une ancienne frontière entre l'Europe et l'Afrique à l'ouest des Alpes. Bull. Soc. Geol. Fr., 2, 547-558.

Boussiga, H., 2008. Géophysique appliquée aux séries paléogènes du Sahel de Tunisie. Tectonique de socle, halocinèse et implications pétrolières. Thèse en Sciences Géologiques. Université Tunis El Manar, 159p. 
Bracène, R., Frizon de Lamotte, D., 2002. The origin of intraplate deformation in the Atlas system of western and central Algeria: from Jurassic rifting to Cenozoic-Quaternary inversion. Tectonophysics 357, 207-226.

Burollet, P. F., Ellouz, N., 1986. L'évolution des bassins sédimentaires de la Tunisie centrale et orientale. Bull. Cent. Rech. Pau, 10, 49-68.

Burollet, P.F., 1991. Structures and tectonics of Tunisia. Tectonophysics 195, 359-369.

Caire, A., 1970. Tectonique de la Méditerranée centrale. Annales de la Société géologique du Nord. 307-346.

Carey, E., 1979. Recherche des directions principales de contraintes associées au jeu d'une population de failles. Rev. Geol. Dyn. Geogr. Phys 21, 57-66.

Carey, E., Brunier, B., 1974. Analyse théorique et numérique d'un modèle mécanique élémentaire appliqué à l'étude d'une population de failles. C. R. Acad. Sci. Ser. D 279, 891-894.

Carey-Gailhardis, E., Mercier, J, L., 1987. A numerical method for determining the state of stress using focal mechanism of earthquake populations: application to Tibetan teleseisms and microseismicity of southern Peru. Earth Planet. Sci. Lett. 82, 165-179.

Catalano, R., Di Stefano, P., Sulli, A., Vitale, F.P., 1996. Paleogeography and structure of the central Mediterranean: sicily and its offshore area. Tectonophysics 260, 291-323.

Catalano, R., Valenti, V., Albanese, C., Accaino, F., Sulli, A., Tinivella, U., Morticelli, M.G., Zanolla C., Giustaniani, M., 2013. Sicily's fold-thrust belt and slab roll-back: the SI.RI.PRO. Seismic crustal transect. Journal of the Geological Society, London, 1-14. doi:10.1144/jgs2012-099.

Catalano, S., De Guidi, G., Lanzafame, G., Monaco, C., Tortorici, L., 2009. Late Quaternary deformation on the island on Pantelleria: new constraints for the recent tectonic evolution of the Sicily Channel Rift (southern Italy). J. Geodyn. 48, 75-82. doi:10.1016/j.jog.2009.06.005.

Catalano, S., De Guidi, G., Romagnoli, G., Torrisi, S., Tortorici, G., Tortorici, L., 2008. The migration of plate boundaries in SE Sicily: influence on the large-scale kinematic model of the African promontory in southern Italy. Tectonophysics 449, 41-62. doi.org/10.1016/j.tecto.2007.12.003. 
Célérier, B., Etchecopar, A., Bergerat, F., Vergely, P., Arthaud, F., Laurent, X., 2012. Inferring stress from faulting: From early concepts to inverse methods. Tectonophysics 581, 206-219. doi.org/10.1016/j.tecto.2012.02.009.

Chihi, L., 1992. Seismotectonic study in Central and Southern Tunisia. Tectonophysics 209, 175-178.

Chihi, L., 1995. Les fossés néogènes à quaternaires de la Tunisie et de la mer pélagienne: étude structurale et leur signification dans le cadre géodynamique de la Méditerranée centrale. Thèse Doct. Es Science. Géol., Tunis, 325 pp.

Chihi, L., Ben Haj Ali, M., Ben Ayed, N., 1992. Mécanismes et signification structurale du plissement dans les chaînes des Chotts (Tunisie méridionale). Analogie avec les plis associés au décrochement E-W de Sbiba (Tunisie centrale). C. R. Acad. Sci. Paris, 315, Série II, 1245-1252.

Chihi, L., Gaaloul, N., Razgallah, S., 2000. Paleoseismic events in Eastern Tunisia (Cap Bon, Sahel): seismites associated with Miocene-Pliocene and Quaternary sediments. Afr. Geosci. Rev. 7(3), 307-314.

Civile, D., Lodolo, E., Tortorici, L., Lanzafame, G., Brancolini, G., 2008. Relationships between magmatism and tectonics in a continental rift: The Pantelleria Island region (Sicily Channel, Italy). Mar. Geol 251, 32-46.

DeMets, C., Gordon, R.G., Argus, D.F., Stein, S., 1994. Effect of recent revisions to the geomagnetic reversal time scale on estimates of current plate motions. Geophysical Research Letters. 21 (20), 2191-2194.

Dercourt, J., Zonenshain, L.P., Ricou, L.E., Kazmin, V.G., Le Pichon, X., Knipper, A.L., Grandjacquet, C., Sbortshikov, I.M., Geyssant, J., Lepvrier, C., Pechersky, D.H., Boulin, J., Sibuet, J.C., Savostin, L.A., Sorokhtin, O., Westphal, M., Bazhenov, M.L., Lauer, J.P., Biju-Duval, B., 1986. Geological evolution of the Tethys belt from the Atlantic to the Pamirs since the Lias. Tectonophysics $123,241-315$.

Dewey, J. F., Helman, M. L., Turco, E., Hutton,D. H.W.\&Knott, S.D., 1989. Kinematics of the Western Mediterranean, in Alpine Tectonics,Vol.45, pp. 265-283, eds Coward, M. P., Dietrich, D. \& Park, R. G., Geological Society Special Publication.

Dlala, M., 1992. Seismotectonic study in Northern Tunisia.Tectonophysics 209 ,171-174. 
Dlala, M., Hfaiedh, M., 1993. Le séisme du 7 novembre 1989 à Metlaoui (Tunisie méridionale): une tectonique active en compression. C. R. Acad. Sci. Paris Série II. 317 (10), 1297-1302.

Dlala, M., Rebaï, S., 1994. Relation compression/extension Miocène supérieur à Quaternaire en Tunisie. C. R. Acad. Sci. Paris Ser. II. 319, 945-950.

Ellouz, N., 1984. Etude de la subsidence de la Tunisie Atlasique orientale et de la mer Pélagienne, Thèse 3ème Cycle, Université Paris VI, 129 pp.

Elter, F.M., Elter, P., Eva, C., Eva, E., Kraus, R.K., Padovano, M., Solarino, S., 2011. Strike-slip geometry inferred from the seismicity of the Northern-Central Apennines (Italy). J. Geodyn, $52,379-388$.

Faccenna, C., Speranza, F., D’ajello Caracciolo, F., Mattei, M., Oggiano, G., 2002. Extensional tectonics on Sardinia (Italy): insights into the arc-back-arc transitional regime. Tectonophysics, 356, $213-232$.

Faccenna, C., Piromallo, C., Crespo Blanc, A., Jolivet, L., Rossetti, F., 2004. Lateral slab deformation and the origin of the arcs of the western Mediterranean. Tectonics 23, TC1012http://dx.doi.org/10.1029/2002TC001488.

Faccenna, C., Molin, P., Orecchio, B., Olivetti, V., Bellier, O., Funiciello, F., Minelli, L., Piromallo, C., Billi, A., 2011. Topography of the Calabria subduction zone (southern Italy): Clues for the origin of Mt. Etna. Tectonics, vol. 30, doi:10.1029/2010TC002694.

Finetti, I., 1984. Geophysical study of the Sicily Channel Rift Zone. Bollettino di Geofisica Teorica ed Applicata 36, 345-368.

Finetti, I.R., Del Ben, A., 2005. Crustal tectono-stratigraphic setting of the Pelagian foreland from new CROP seismic data. In: Finetti, I.R. (Ed.), CROP PROJECT: Deep Seismic Exploration of the Central Mediterranean and Italy. Elsevier B.V, pp. 581-595.

Frizon de Lamotte, D., Leturmy, P.,Missenard, Y., Khomsi, S., Ruiz, G., Saddiqi, O., Guillocheau, F., Michard, A., 2009. Mesozoic and Cenozoic vertical movements in the Atlas system (Algeria,Morocco, Tunisia): an overview. Tectonophysics 475, 9-28.

Frizon de Lamotte, D., Raulin, C., Mouchot, N., Wrobel-Daveau, J.-C., Blanpied, C., Ringenbach, J.-C., 2011. The southernmost margin of the Tethys realm during the Mesozoic and Cenozoic: 
Initial geometry and timing of the inversion processes. Tectonics, 30, TC3002, doi: org/10.1029/ 2010TC002691.

Frizon de Lamotte, D., Saint Bezar, B., Bracene, R., Mercier, E., 2000. The two main steps of the Atlas building and geodynamics of the western Mediterranean. Tectonics, 19, 740-761.

Gallais, F., Gutscher, M. A., Graindorge, D., Chamot-Rooke, N., Klaeschen, D., 2011. A Miocene tectonic inversion in the Ionian Sea (central Mediterranean): Evidence from multichannel seismic data, J. Geophys. Res., 116, doi:10.1029/2011JB008505.

Gardiner, W., Grasso, M., Sedgely, D., 1995.Plio-Pleistocene fault movement as evidence for megablock kinematics within the Hyblean-Malta Plateau, Central Mediterranean. J. Geodyn. $19,35-51$.

Gharbi, M., 2013. Interactions entre le front sud-atlasique et la marge est-tunisienne (Chott-Golfe de Gabès): analyse tectono-sédimentaire, cinématique de failles et coupe équilibrée. AixMarseille University PhD Thesis, 167 p.

Gharbi, M., Masrouhi, A., Espurt, N., Bellier, O., Amari, E. A., Ben Youssef, M., Ghanmi, M., 2013. New tectono-sedimentary evidences for Aptian to Santonian extension of the Cretaceous rifting in the Northern Chotts range (Southern Tunisia). J. Afr. Earth Sci. 79, P58-73, doi.org/10.1016/j.jafrearsci.2012.09.017.

Ghribi, R., Bouaziz, S., 2010. Neotectonic evolution of the Eastern Tunisian platform from paleostress reconstruction. J. H. Mines and Environmental Research. ISSN: 2107-6510, V. 1. 14-25

Goes, S., Giardini, D., Jenny, S., Hollenstein, C., Khale, H. G. \& Geiger, A., 2004. A recent tectonic reorganization in the south-central Mediterranean, Earth. Planet. Sci. Let. 226, 335-345.

Gomez, F., Allmendinger, R., Barazangui, M., Er-Raji, A., Dahmani, M., 1998. Crustal shortening and vertical strain partitioning in the Middle Atlas mountains of Morocco. Tectonics. 17, 520-533.

Gueddiche, M., 1992. Analyse de la sismicité en Tunisie et l'étude sismique, sismotectonique et néotectonique de la Tunisie Septentrionale. Thèse de Doctorat de Spécialité, Université Paris VI, France, 216 pp

Guiraud, R., Bosworth, W., Thierry, J., Delplanque, A., 2005. Phanerozoic geological evolution of Northern and Central Africa: an overview. J. Afr. Earth Sci. 43, 83-143. 
Haller, P., 1983. Structure profonde du Sahel Tunisien. Interprétation géodynamique. Thèse 3ème cycle, Univ. Franche Comité, Besançon, France, 162 pp

Herkat, M., Guiraud, R., 2006. The relationships between tectonics and sedimentation in the Late Cretaceous series of the Eastern Atlasic Domain (Algeria). J. Afr. Earth Sci. 46, 346-370.

Hfaiedh, M., 1983. Etude sismotectonique de la Tunisie nord-orientale. Thèse, Univ. Paris VI.

Hfaiedh, M., Ben Ayed, N., Donee, L., 1985. Etude néotectonique et seismotectonique de la Tunisie nord-orientale. Notes Serv. geol. Tunisie 51, 41-55, ONM-Tunis.

Hippolyte, J. C., Bergerat, F., B. Gordon, M., Bellier, O., Espurt, N., 2012. Keys and pitfalls in mesoscale fault analysis and paleostress reconstructions, the use of Angelier's methods, Tectonophysics. doi.org/10.1016/j.tecto.2012.01.012.

Homberg C., Hu J.-C., Angelier J., Bergerat F., Lacombe, O., 1997. Characterization of stress perturbations near major fault zones : insights from field studies (Jura Mountains) and numerical modelling. J. Struct. Geol., 19, 5, 703-718

Kherroubi, A., Déverchère, J., Yelles, K., Mercier de Lépinay, B., Domzig, A., Cattaneo, A., Bracène, R., Gaullier, V., Graindorge, D., 2009. Recent and active deformation pattern off the easternmost Algerian margin, Western Mediterranean Sea: New evidence for contractional tectonic reactivation. Marine Geology, Special Issue on EUROMARGINS. 261, 17-32.

Lacombe, O., Mouthereau, F., Angelier, J., Deffontaines, B., 2001. Structural, geodetic and sismological evidence for tectonic escape in SW Taiwan. Tectonophysics, 333, 323-345, doi.org/10.1016/S0040-1951(00)00281-X.

Lacombe O., Mouthereau, F., Kargar, S., Meyer, B., 2006. Late Cenozoic and modern stress fields in the western Fars (Iran) : implications for the tectonic and kinematic evolution of Central Zagros. Tectonics, 25, TC1003. Doi: 10.1029/2005TC001831.

Lacombe, O., 2012. Do fault slip data inversions actually yield "paleostresses" that can be compared with contemporary stresses? A critical discussion. C. R. Geoscience. 344. 159-173, doi.org/10.1016/j.crte.2012.01.006.

Laville, E., Delcaillau, B., Charroud, M., Dugué. O., Ait Brahim, L., Cattaneo, G., Deluca, P., Bouazza, A., 2007. The Plio-Pleistocene evolution of the Southern Middle Atlas Faults Zone (SMAFZ) front of Morocco. Int. J. Earth Sci 96. 497-515 
Le Pichon, X., Bergerat, F., Roulet, M.-J., 1988. Plate kinematics and tectonics leading to Alpine belt formation: a new analysis. Processes in Continental Lithospheric Deformation. Geol. Soc. Am. Spec. 218, 111-131.

Mannaï-Tayech, B., 2009. The lithostratigraphy of Miocene series from Tunisia revisited, J. Afr. Earth Sci., 54, , 53-61. doi:10.1016/j.jafrearsci.2009.02.003.

Mantovani, E., Babbucci, D., Tamburelli, C., Viti, M., 2009. A review on the driving mechanism of the Tyrrhenian-Apennines system: implications for the present seismotectonic setting in the Central-Northern Apennines. Tectonophysics 476, 22-29.

Marchal, D., Guiraud, M., Rives, T., 2003. Geometric and morphologic evolution of normal fault planes and traces from 2D to 4D data. J. S. Geol 25, 135-158.

Masrouhi, A. Bellier, O., Koyi, H. Vila, J.M., Ghanmi, M. 2013. The evolution of the Lansarine-Baouala salt canopy in the North African Cretaceous passive margin in Tunisia, Geological Magazine, 150, 5, 835-861., doi:10.1017/S0016756812000763.

Masrouhi, A., Ghanmi, M., Ben Slama, M.-M., Ben Youssef, M., Vila, J. M, Zargouni, F. 2008. New tectono-sedimentary evidence constraining the timing of the positive tectonic inversion and the Eocene Atlasic phase in northern Tunisia: Implication for the North African paleo-margin evolution. C. R. Geosciences 340, 771-778. doi:10.1016/j.crte.2008.07.007.

Masrouhi, A., Ghanmi, M., Youssef, M.B., Vila, J.M., Zargouni, F., 2007. Mise en évidence d'une nappe de charriage à deux unités paléogènes au plateau de Lansarine (Tunisie du Nord): Définition d'un nouvel élément structural de l'Atlas Tunisien et réévaluation du calendrier des serrages tertiaires: C.R. Geosciences 339, 441-448. doi:10.1016/j.crte.2007.03.007.

Masrouhi, A., Koyi, H. A., 2012. Submarine 'salt glacier' of Northern Tunisia, a case of Triassic salt mobility in North African Cretaceous passive margin. In Salt Tectonics, Sediments and Prospectivity (eds. Alsop, G. I., Archer, S. G., Hartley, A. J., Grant, N. T. \& Hodgkinson, R), pp. 579-593. Geological Society of London, Special Publication no. 363, doi:10.1144/SP363.29.

Mejri, F., Burollet, P.F., Ben Ferjani, A., 2006. Petroleum geology of Tunisia, A renewed Synthesis. Entreprise Tunisienne des Activités Pétrolières. 230 pp. 
Mercier, J.L., Carey-Gailhardis, E., Sébrier, M., 1991. Paleostress determinations from fault kinematics: application to the neotectonics of the Himalayan-Tibet and the central Andes. Philos. Trans. R. Soc. Lond. Ser. A 337, 41-52.

Mercier, J.L., Vergely, P., Zhang, Y. Q., Hou, M. J., Bellier, O., Wang, Y. M., 2013. Structural records of the Late Cretaceous-Cenozoic extension in Eastern China and the kinematics of the Southern Tan-Lu and Qinling Fault Zone (Anhui and Shaanxi provinces, PR China). Tectonophysics 582, $50-75$.

Michard, A., Chalouan, A., Feinberg, H., Goffé, B., Montigny, R., 2002. How does the Alpine belt end between Spain and Morocco. Bull. Soc. Geol. Fr. 173, 3-15.

Morelli, A., Barrier, E., 2004. Geodynamic map of the Mediterranean, sheet 2, Comm. for the Geol. Map of the World, Paris.

Nocquet, J.M. \& Calais, E., 2004. Geodetic measurements of crustal deformation in the Western Mediterranean and Europe, Pure Appl. Geophys. 161, 661-681.

Nocquet, J.M., 2012. Present-day kinematics of the Mediterranean: A comprehensive overview of GPS results, Tectonophysics, 579, p. 220-242.

Patriat, M., Ellouz, N., Dey, Z., Gaulier, J.-M., Ben Kilani, H., 2003. The Hammamet, Gabes and Chotts basins (Tunisia): a review of the subsidence history. Sediment. Geol. 156, 241-262.

Philip, H., Andrieux, J., Dlala, M., Chihi, L., Ben Ayed, N., 1986. Evolution tectonique mio-plioquaternaire du fosse' de Kasserine (Tunisie centrale). Bull. Soc. Geol. Fr. 8 (4), 559-568.

Piqué, A., Tricart, P., Guiraud, R., Laville, E., Bouaziz, S., Amrhar, M., Ait Ouali, A., 2002. The Mesozoic-Cenozoic Atlas belt (North Africa): an overview. Geodinamica Acta. 15 (3), 185208.

Rebaï, S., Philip, H., Taboada, A., 1992. Modern tectonic stress field in the Mediterranean region; evidence for variation in stress directions at different scales. Geophys. J. Int. 110, 106-140.

Rekhiss, F., 2008. Evolution du système de convergence Europe-Afrique et progression de la déformation en Tunisie. Procedings of the 11th Tunisian Petroleum Exploration \& Production Conference Tunis, October. 162-172. 
Renda, P., Tavarnelli E., Tramutoli M., Gueguen E., 2000. Neogene deformations of Northern Sicily, and their implications for the geodynamics of the Southern Tyrrhenian Sea margin, Mem. Soc. Geol. Ital. 55, 53-59.

Roure, F., Casero, P., Addoum, B., 2012. Alpine inversion of the North African margin and delamination of its continental lithosphere. Tectonics, Vol. 31, TC3006, doi:10.1029/2011TC002989.

Said, A., Dominique, C., Baby, P., Ouali, J., 2011a. Active oblique ramp faulting in the Southern Tunisian Atlas. Tectonophysics 499, 178-189.

Said, A., Baby, P., Dominique, C., Ouali, J., 2011b. Structure, paleogeographic inheritance, and deformation history of the southern Atlas foreland fold and thrust belt of Tunisia. Tectonics, Vol. 30, TC6004, doi:10.1029/2011TC002862.

Sebei, K., Inoubli, M.H., Boussiga, H., Tlig, S., Alouani, R., Boujamaoui, M., 2007. Seismic stratigraphy, tectonics and depositional history in the Halk El Menzel region, NE Tunisia. J. Afr. Earth Sci. 47, 9-29.

Serpelloni, E., Vannucci, G., Pondrelli, S., Argnani, A., Casula, G., Anzidei, M., Baldi, P., Gasperini, P., 2007. Kinematics of the Western Africa-Eurasia plate boundary from focal mechanisms and GPS data. Geophysical Journal International 169, 1180-1200.

Shabanian, E., Bellier, O., Abbassi, M.R., Siame, L., Farbod, Y., 2010. Plio-Quaternary stress states in NE Iran: Kopeh Dagh and Allah Dagh-Binalud mountain ranges. Tectonophysics 480, 280-304.

Siame, L.L., Shabanian, E., Bellier, O., 2009. Extrusion tectonics and subduction in the eastern South Caspian region since $10 \mathrm{Ma}$ : Comment. Geology 37 (12), 197-198.

Taktak, F., Bouaziz, S., Tlig, S., 2012. Depositional and tectonic constraints for hydrocarbon targets of the Lutetian-Langhian sequences from the Gulf of Gabes-Tunisia. J. Pet. Sci. Eng. V, 82-83, $50-65$

Taktak, F., Kharbachi, S., Bouaziz, S., Tlig, S., 2010. Basin Dynamics and Petroleum Potential of the Eocene Series in the Gulf of Gabes, Tunisia. J. Pet. Sci. Eng. V, 75, 114-128.

Tapponnier, P., 1977. Evolution tectonique du système alpin en Méditerranée: poinçonnement et écrasement rigide-plastique. Bull. Soc. Geol. Fr. 7, 437-460. 
Tlig, S., Erraioui, L., Aissa, L. B., Alouani, R., Tagorti. M. A., 1991. Tectogenèses alpine et atlasique, deux événements distincts dans l'histoire géologique de la Tunisie. Corrélation aux événements clés en Méditerranée, C. R. Acad. Sci. II, 312, 295-301.

Tlig, S., Sahli, H., Er-Raioui, L., Alouani, R., Mzoughi, M., 2010. Depositional environment controls on petroleum potential of the Eocene in the North of Tunisia. J. Pet. Sci. Eng. 71, 91-105, doi.org/10.1016/j.petrol.2010.01.009.

Torelli, L., Zitellini, N., Argnani, A., Brancolini, G., De Cillia, C., Peis, D., Tricart, P., 1991. Sezione geologica crostale dall'avampaese Pelagiano al Bacino di retroarco Tirrenico (Mediterraneo centrale).Mem. Soc. Geol. Ital. 47, 385-399.

Touati, M.A., Rodgers, M.R., 1998. Tectono-stratigraphic history of the Southern gulf of Gabes and the hydrocarbon habitats. Proceedings of the Sixth Tunisian Exploration and Production Conference (Tunis, May: 5-9), 343-370.

Vially, R., Letouzey, J., Bernard, F., Haddadi, N., Desforges, G., Askri, H. Boudjema, A., 1994. Basin inversion along the North African Margin.The Saharan Atlas (Algeria), in Peri-Tethyan Platforms, pp. 9-118, 79-118, ed. Roure, F., Technip, Paris.

Villemin, T., Bergerat, F., Angelier, J., Christian, L., 1994. Brittle deformation and fracture patterns on oceanic rift shoulders; the Esja Peninsula, SW Iceland. Journal of Structural Geology 16, 1641-1654.

Wallace, R. E., 1951. Geometry of shearing stress and relation to faulting. J. Geol., 59, 118-130.

Winnock, E., 1981. Structure du Bloc Pelagien. In: Wezel, I.F.C. (Ed.), Sedimentary Basins of Mediterranean Margins. Tecnoprint, Bologna, pp. 445-464.

Zargouni, F, Termolières J.C., 1981. Déformations tectoniques postérieures au dépôt de la série du Segui (Plio-Villafranchien) dans l'Atlas méridional tunisien. Actes 1er Cong. Nation. Sci. Terre, Tunis

Zargouni, F., 1984. Style et chronologie des déformations des structures de l'Atlas tunisien méridional. Évolution récente de l'accident Sud-atlasique. C.R. Acad Sci. Paris (Série II, no. 2), 179-196. 
Zargouni, F., Ruhland., 1981. Style des déformations du quaternaire récent lié au coulissement de la faille de Gafsa et chronologie des phases tectoniques de l'Atlas méridional de Tunisie. C. R. Acad. Sc. Paris. T. 292. 913-915.

Zouari, H., Turki, M. M., Delteil, J., 1990. Nouvelles données sur l'évolution tectonique de la chaîne de Gafsa, Bull. Soc. Geol. Fr. V, 6, 621-628.

Zouari, H., Ouled Ghrib, A., Ben Ouezdou, Zargouni, F., H., Chouachi, A., Laatar, E., 1991. Geological map of El Ayacha, scale 1/100.000, $n^{\circ} 67$. Institut National de recherche Scientifique de Tunisie, Service Géologique Nationale de l'Office Nationale de Mines, Tunisia.

\section{Figures captions}

Figure 1: Tectonic map of the Atlas belt within its geodynamics context. Gray arrows correspond to the present-day horizontal compression direction of Nubia with respect to Eurasia (after Michard et al., 2002; Faccenna et al., 2004; Serpelloni et al., 2007; Billi et al., 2011). Red arrows correspond to the sense of displacement of the Nubian plate with respect to the Eurasian plate. Red square indicates the location of the study area.

Figure 2: (A) Structural map of the Southern Tunisian Atlas and Gulf of Gabes domain. (B) Geologic map of the studied region (Boxed area in A) where are located the kinematic measurement sites. The map is simplified from the geological map of Tunisia $1 / 500.000$ scale (Ben Haj Ali et al., 1985).

Figure 3: $(a, b)$ An example of crosscutting relationships between two distinct slip generations recorded on a fault plane and pebble faces within Quaternary conglomerates (site 91A). (c) Chronology, i.e., cross-cutting relationship, between different families of slip vectors measured on fault planes in several sites. Fault planes and measured slip vectors (arrows on fault planes) are plotted, arrows point in the horizontal slip azimuth direction. Arrows inside stereograms represent the horizontal slip azimuth direction. Numbers describe individual fault plane measurement; oldest slip vectors on each fault plane are indicated by .1, the second one by .2. Stratifications are presented by reported red dashed plane.

Figure 4: Lower hemisphere stereograms of fault slip data together with the inversion results of the paleostress state presented in Table. 1. Fault planes and measured slip vectors (arrows on fault planes) are plotted. Large arrows outside stereograms represent the direction of maximum $\left(\sigma_{1}\right.$, convergent, black arrows) and minimum ( $\sigma_{3}$, divergent, gray arrows) horizontal stress axes. Histograms show distribution of deviation angles between the measured and calculated slip vectors (e.g., Angelier, 1979; Bellier and Zoback, 1995; Lacombe, 2012). Numbers outside the stereoplots refer to sites marked in Fig. 2 as well as in Table. 1. Stratifications are presented by reported red dashed plane. See Fig. 6 caption for other descriptions. 
Figure 5: Lower hemisphere stereograms of fault slip data together with the inversion results of the modern stress state presented in Table. 1. Detailed figure captions are given in the Figure 4 captions. The stereograms indicated by asterisk (S292) are the "fixed" solutions (Bellier and Zoback, 1995) for fault data populations comprised of less than four well distributed fault directions.

Figure 6: Trend of $\sigma_{1}$ (maximum horizontal stress) axis for the strike-slip and compressional stress regimes deduced from the fault kinematic inversions (Table. 1 and Figs. 4 and 5). (a) Paleostress state (b) Modern stress state (see Fig. 2B for location of this figure).

Figure 7: Lower hemisphere stereograms of fault slip data together with the inversion results of the recent stress states resulting from measurement in the Quaternary terraces. Numbers (at the bottom of stereograms) refer to sites marked in Fig. 2 as well as in Table. 1. Detailed figure captions are same than for the Figure. 4. Bedding is reported by red dashed plane for the site S281. Measurements in sites $91 \mathrm{~A}$ and 024 have been done in non tilted terrace beds. At top left of stereograms are reported the stress axes characteristics (azimuth / plunge) given by inversions (see Table.1)

Figure 8: Fault scale geological expression of the modern stress states in the SAFT. A: The E trending thrust fault bounding the front of Orbata anticline and affecting the Miocene-Pliocene deposits. B: Evidences for the recent active tectonics at the southern flank of the Chemsi anticline. (a) Eastlooking view of the southern front of the Chemsi anticline. (b) and (c): detailed view of The Chemsi back-thrust showing a recent faulting of Coniacian-Santonian marls overthrusting the Segui formation and bending a Quaternary terrace.

Figure 9: Detailed geological map of the Koudiat Hammamet (Southeastern of the Chemsi and Orbata anticline, see Fig. 2B), associated with the site A31 (Table. 1). B: The N110 ${ }^{\circ}$ trending strike-slip fault of the Koudiat Hammamet affected the Quaternary deposits (see Fig. 2B). Crosscutting striations recorded on this fault plane indicates two distinct slip generations. A311 and A312 : Lower hemisphere stereograms of fault slip data providing evidence for two distinct stress regimes, same caption as Fig. 4

Figure 10: Map of Tunisian Atlas associated with earthquake focal mechanisms data are from the National Meteorological Institute (Tunis), the Harvard CMT and the European Regional Catalogues. Horizontal projections of $\mathrm{P}$ (in black) and $\mathrm{T}$ (in gray) axes. Red $=$ normal faulting, blue $=$ thrust faulting, green = strike-slip faulting, and black = unknown stress regime (see text for details).

Figure 11: Seismic reflexion sections L35 and L155 across the Gulf of Gabes, showing NW trending horst and graben systems related to the NE extension of the recent Pelagian Sea. On the left of these seismic lines, the map shows the position of seismic sections and the locations of petroleum wells used in our interpretation. It defines the major fault and their role in the Cenozoic and Quaternary structural evolution of the Gulf of Gabes. 
Figure 12: Structural sketch map of the Central Mediterranean showing the main present-day structural and geodynamics features (Chihi, 1995; Renda et al., 2000; Michard et al., 2002; Morelli and Barrier, 2004; Goes et al., 2004; Serpelloni et al., 2007; Billi et al., 2011; Faccenna et al., 2011; Catalano et al., 2013). Magenta arrows show the recent stress strike in the Tunisian atlas domain. The Black arrows indicate the relative trend of velocity predicted by Nubia-Eurasia. Blue arrows correspond to the mean Pelagian Sea opening. Light pink arrows show the sense of displacement of the Ionian Basin.

Table 1: The results of fault kinematics inversions characterizing the Mio-Plio-Quaternary stress regimes.

The used inversion method (e.g., Carey, 1979) assumes that the slip represented by the striation occurs in the direction of the resolved shear. Reduced principal stress axes: $\sigma_{1}, \sigma_{2}, \sigma_{3}$, are the compressional, intermediate and extensional reduced stress axes, respectively. $R=\left(\sigma_{2}-\sigma_{1}\right) /\left(\sigma_{3}-\sigma_{1}\right)$, is the stress ratio of the stress tensor, a linear quantity describing relative stress magnitudes. Site numbers refer to Figs. $2 \mathrm{~B}$ and 3 to 6 . N, number of fault slip pairs considered for stress calculation; Rm, stress regime: C, compressional; S, strike-slip; Q, quality: A, well-constrained; B, constrained; C, poorly constrained solutions. For the fault data populations comprised of less than four well distributed fault directions, a "fixed" solution (Bellier and Zoback, 1995) was applied, in which the principal stress axes are fixed to lie in horizontal and vertical planes; the results were marked as " $\mathrm{CF}$ " quality. The site numbers marked by " $\mathrm{A}$ " or " $\mathrm{B}$ " indicate additional stress tensors obtained at those sites. All angles are in degree.

The abbreviations are: Cong : Conglomerates; Limes: Limestones; Up-Cret/Tor-Plio: Upper Cretaceous/Tortonian-Pliocene; Up-Cret/Quat: Upper Cretaceous/Quaternary; Eoc/Quat: Eocene/Quaternary; Tor-Plio: Tortonian-Pliocene; Quat-Terr: Quaternary terraces. The references are : 1: Ben Haj Ali et al., 1985; 2: Zouari et al., 1991; 3: Mannaï-Tayech, 2009; 4: Gharbi, 2013.

For site S292 in Fig. 4 indicated with an asterisk, the modern stress solution (fixed and standard) are presented due to the restricting effects of fault planes nearly parallel to the $\sigma_{1}$ axis, on the stress tensor determined by the standard solution.

Table 2: Focal mechanisms used for showing horizontal projections of $P$ and $T$ deformation axes that prevail in southern Tunisian Atlas front and Pelagian Sea. Data are from the RCMT catalog (19972007, http://mednet.rm.ingv.it/quick rcmt.php), Harvard data (http://www.seismology.harvard), EHTZ data (http://www.seismo.ethz.ch/prod/tensors/mt_autom/index_EN), National Institute of Meteorology and Dlala and Hfaiedh, 1993. 


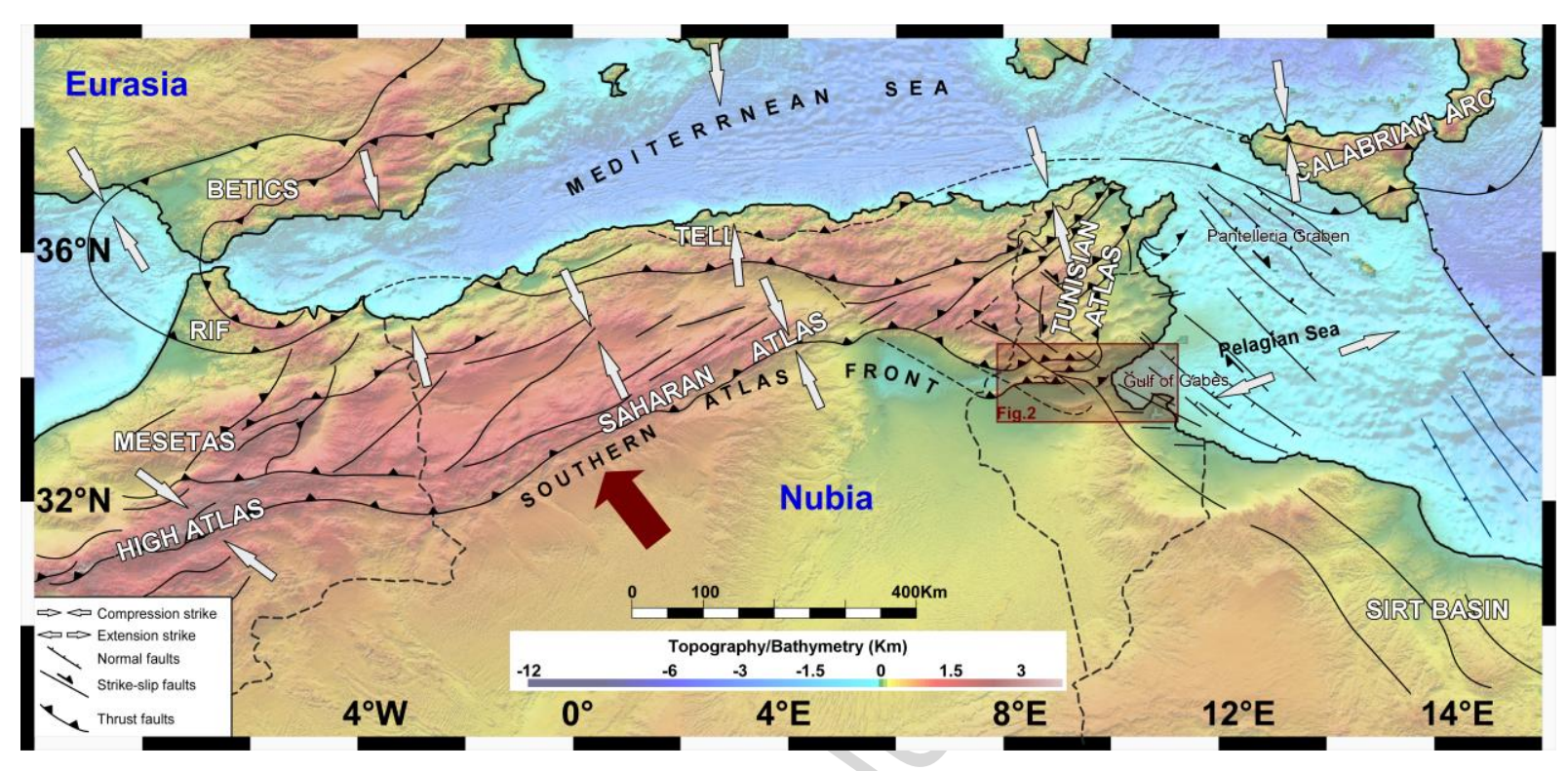

Figure 1 

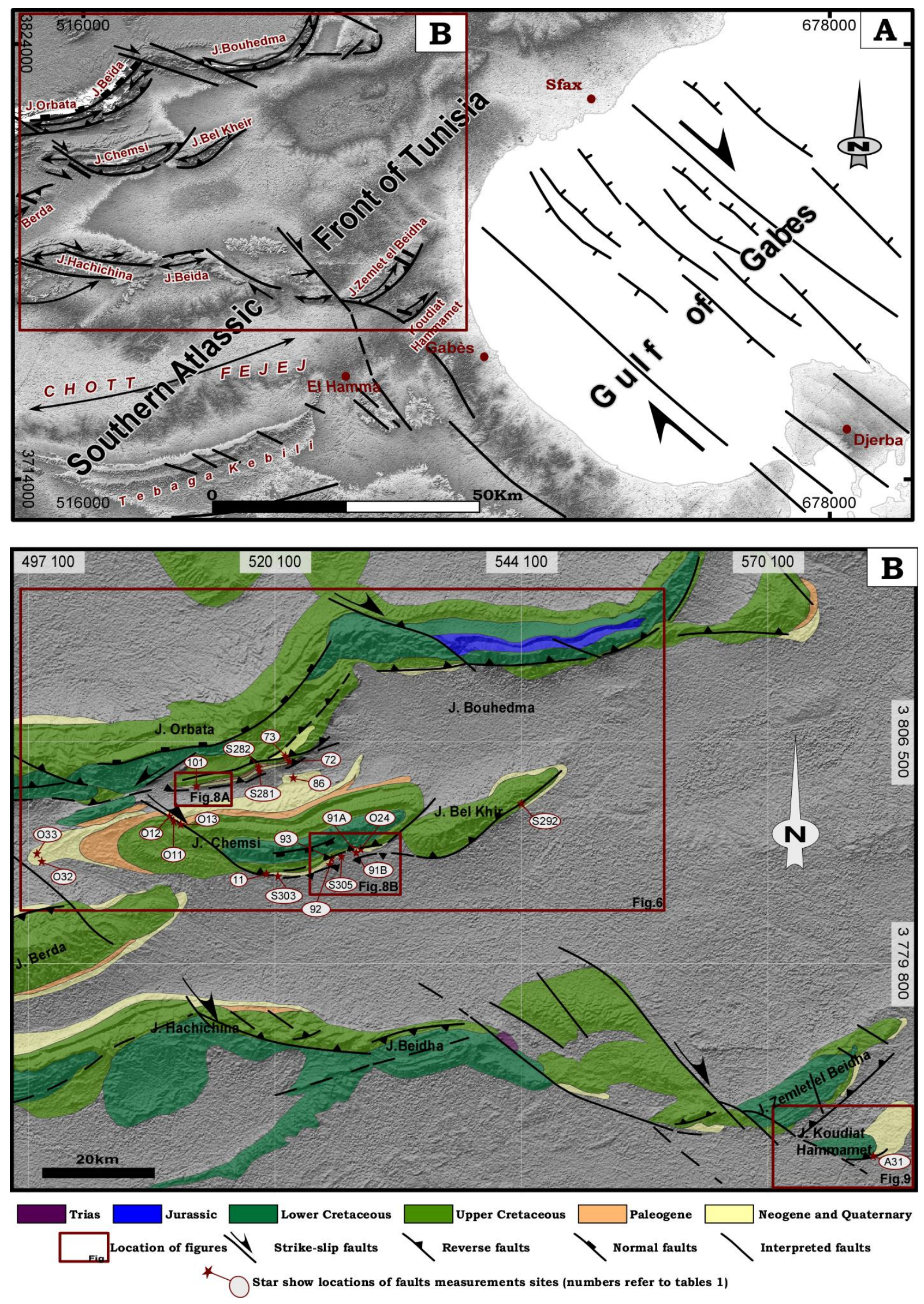

Figure 2 


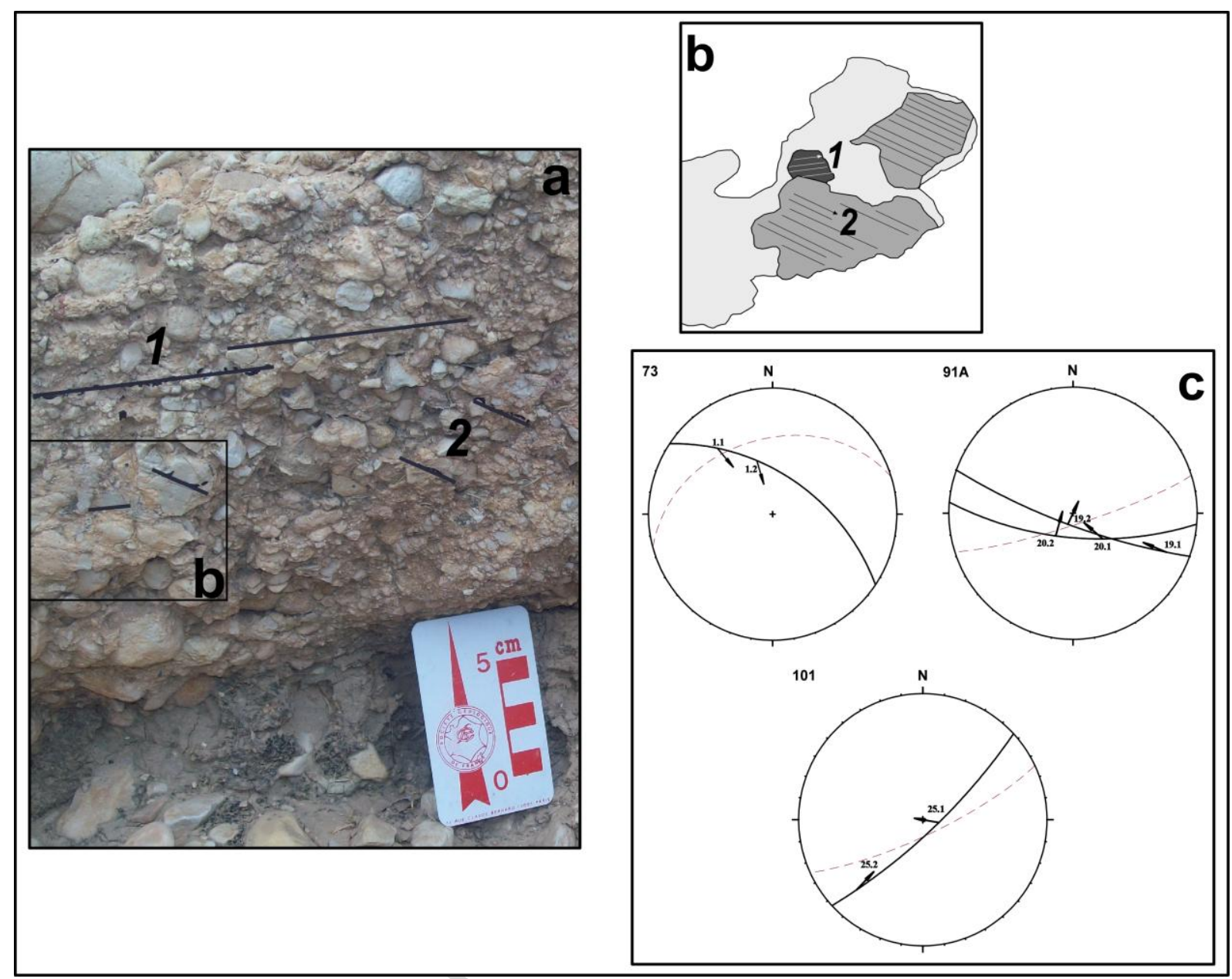

Figure 3 


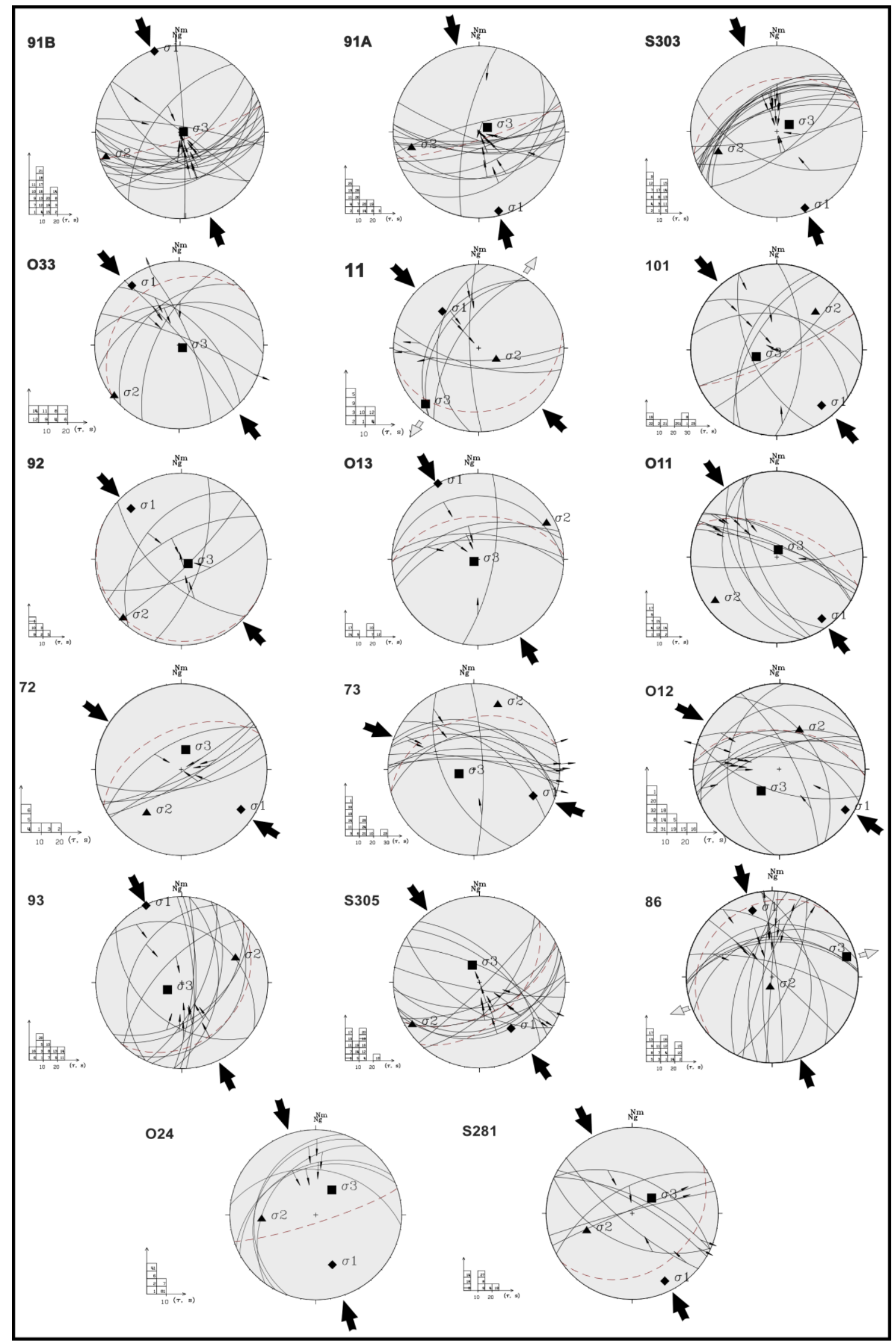

Figure 4 


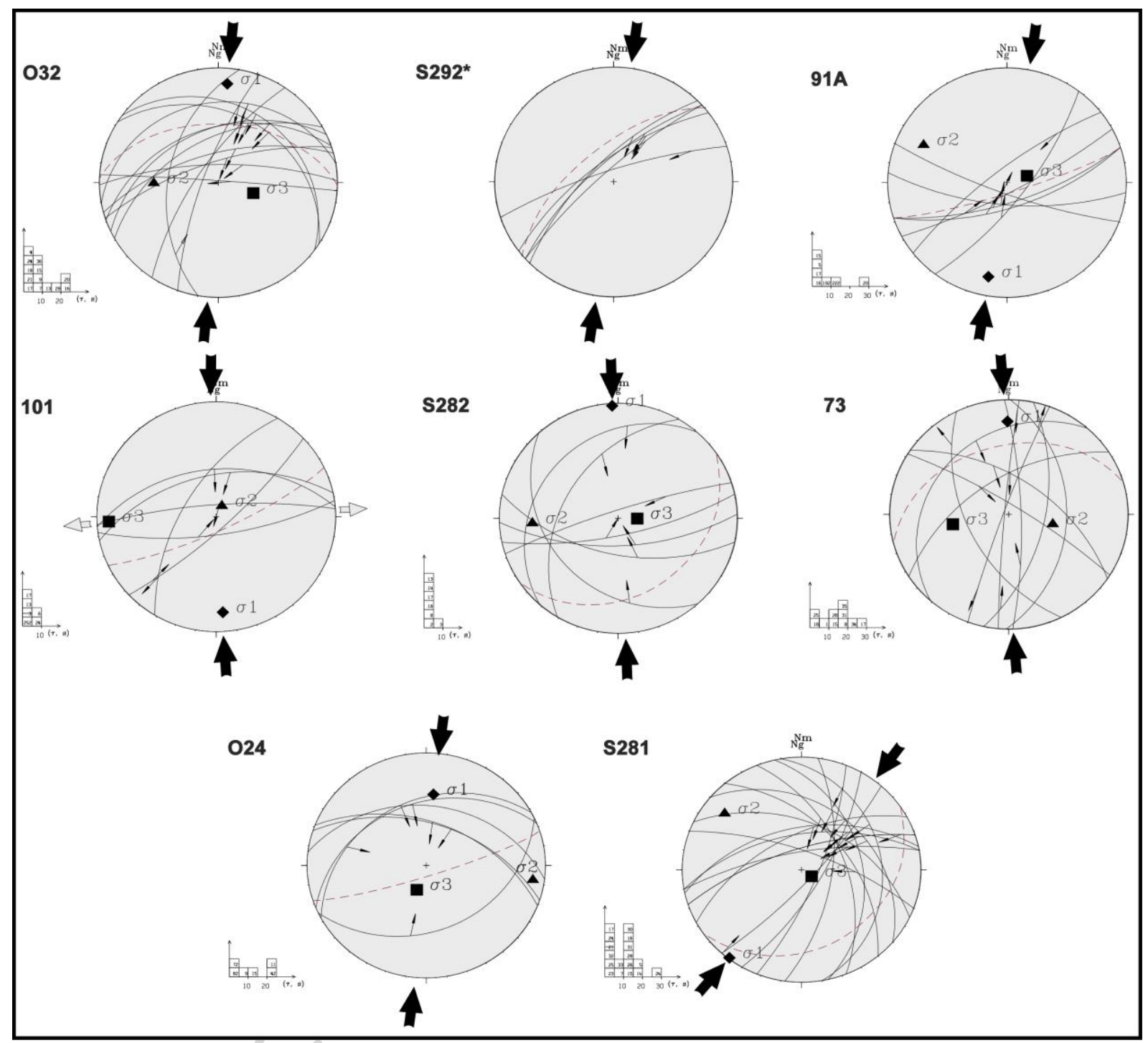

Figure 5 

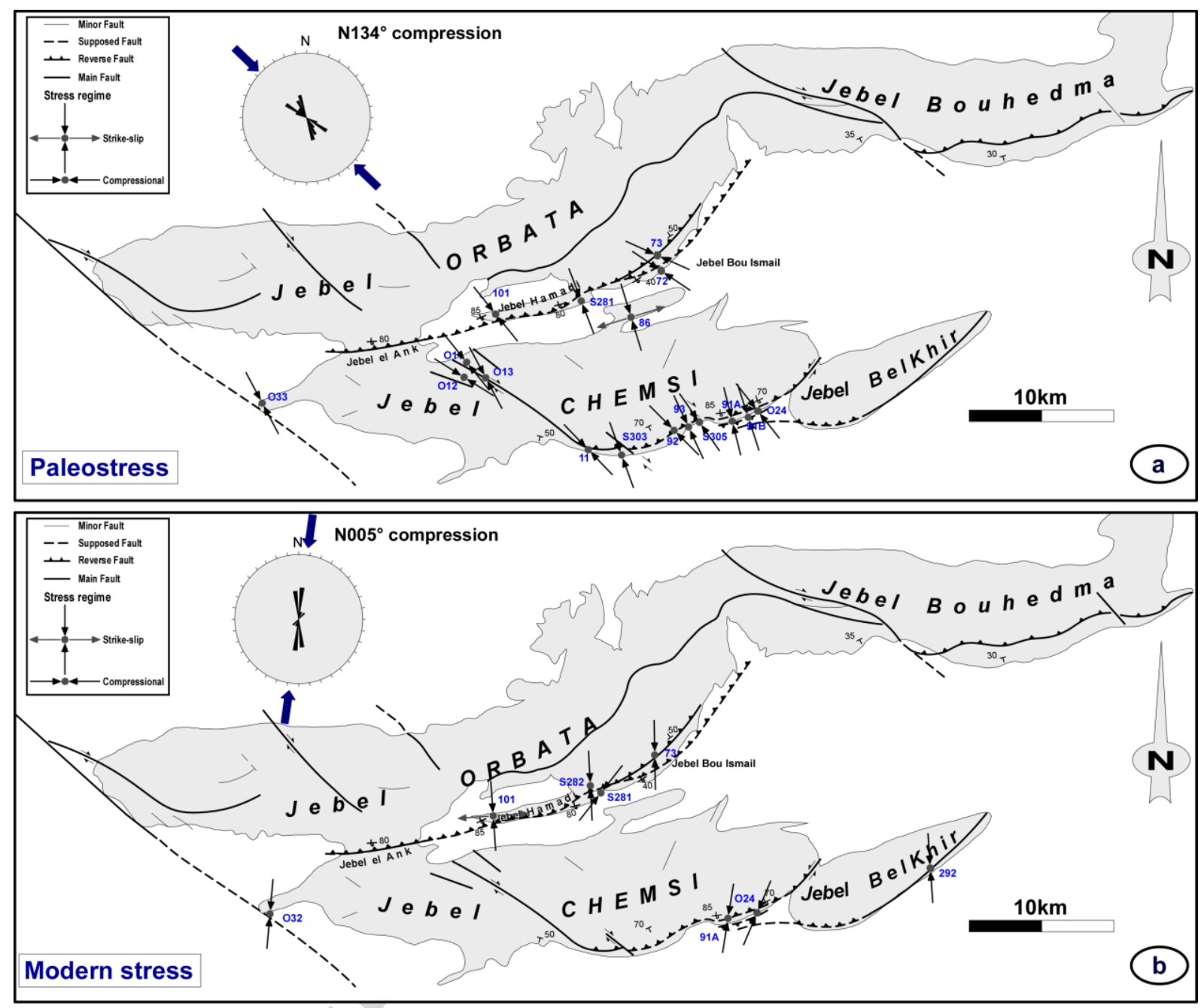

Figure 6 


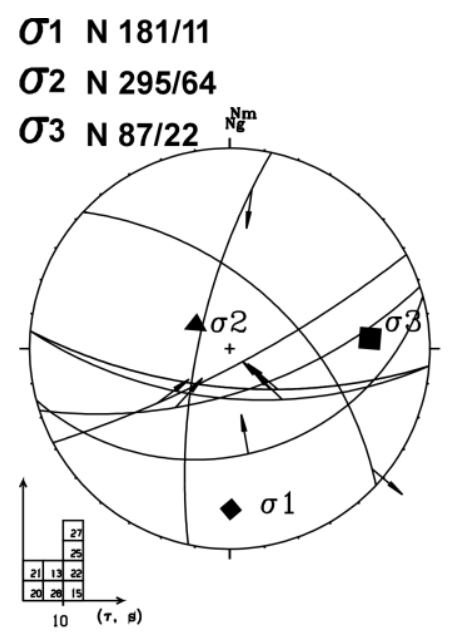

91AQ
O1 N 002/07

$\sigma 2 \mathrm{~N} 106 / 70$

$\sigma 3 \mathrm{~N} 268 / 18_{8}^{\mathrm{Nm}}$

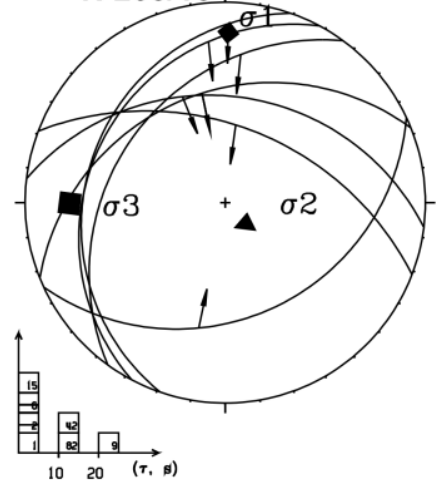

O24Q $\sigma 1 \mathrm{~N} 200 / 10$

$\sigma 2 \mathrm{~N} 293 / 16$

$\sigma_{3} \mathrm{~N} 071 / 79_{\mathrm{g}}^{\mathrm{Nm}}$

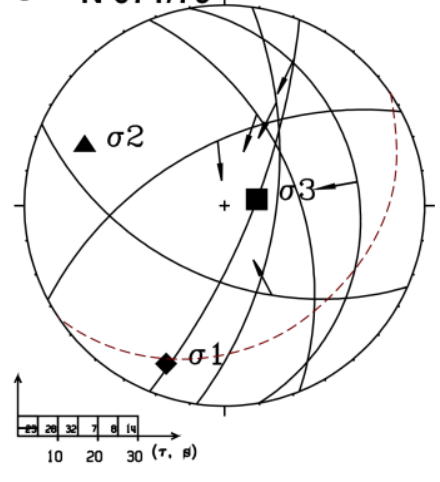

S281Q

Figure 7 


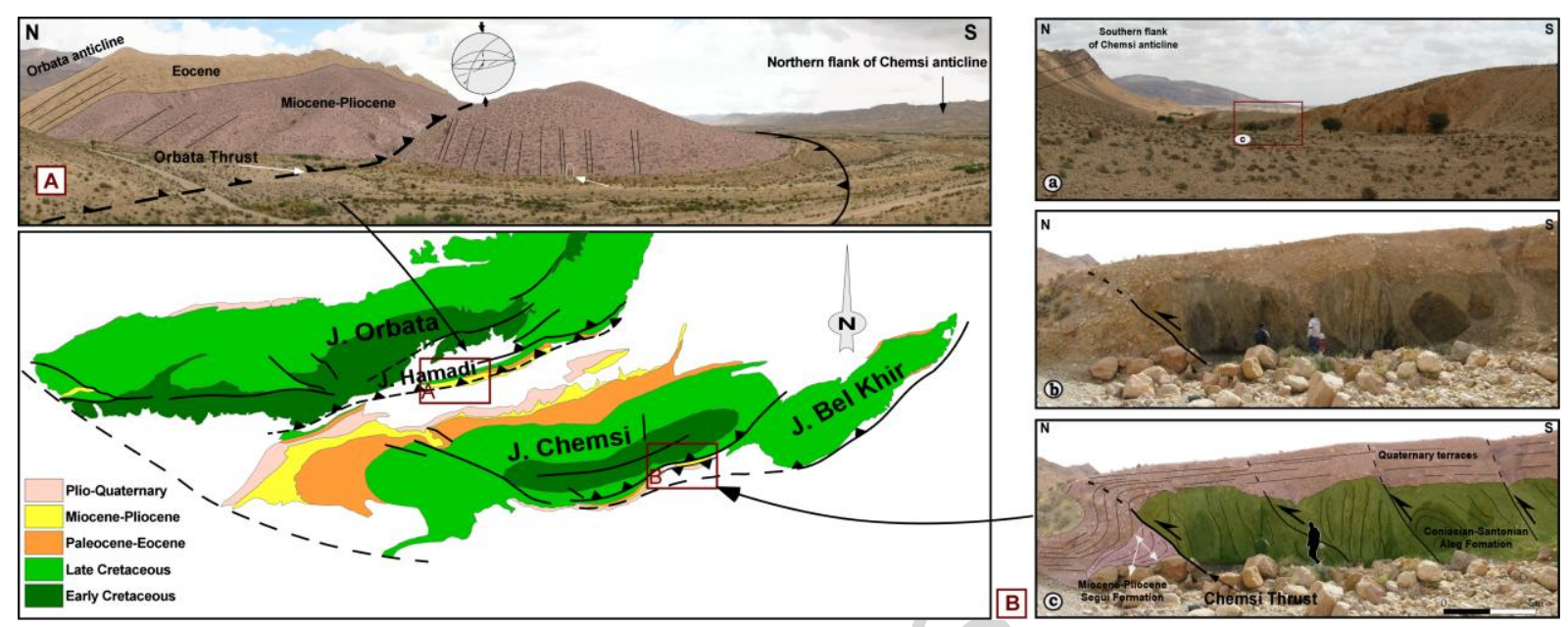

Figure 8 


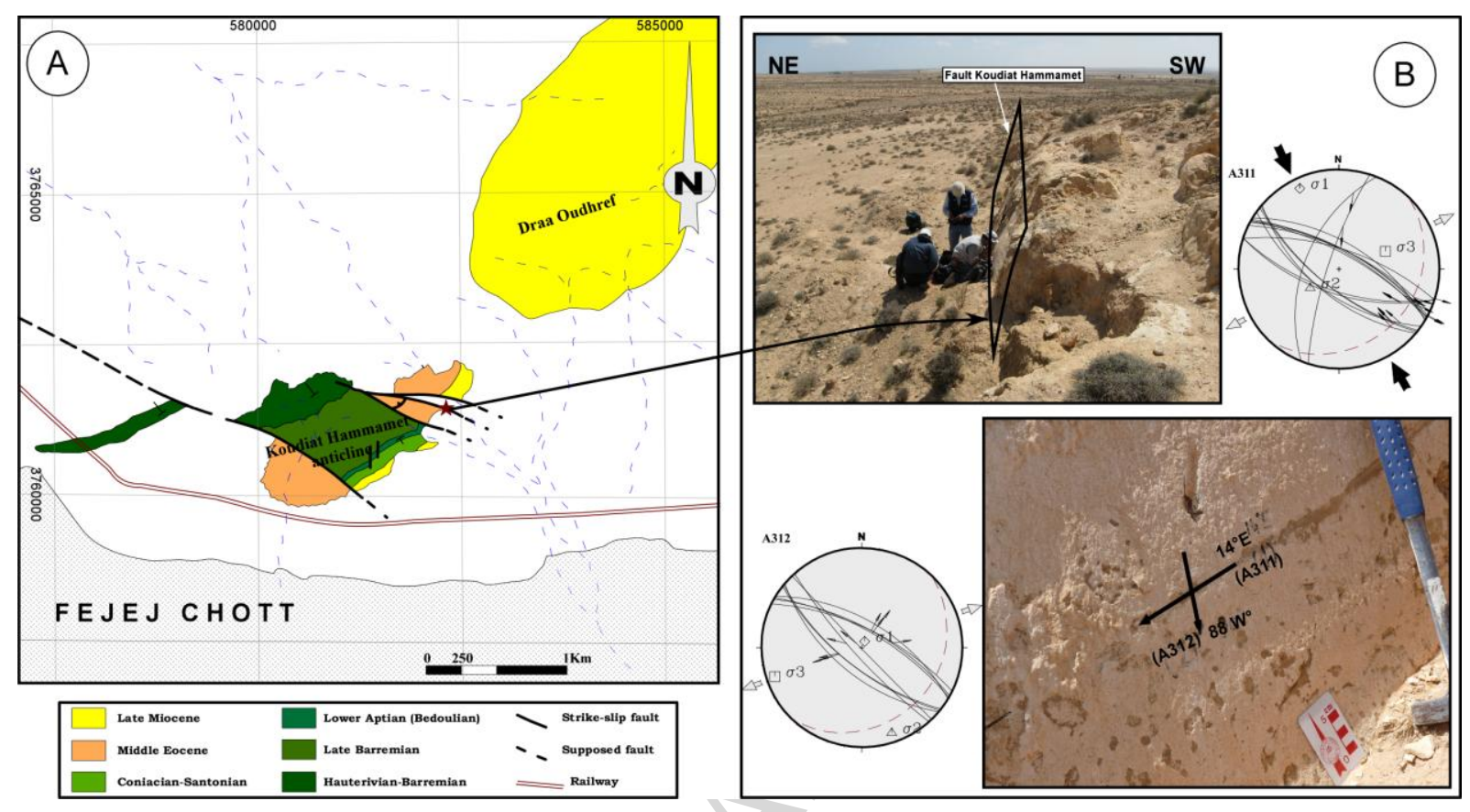

Figure 9 


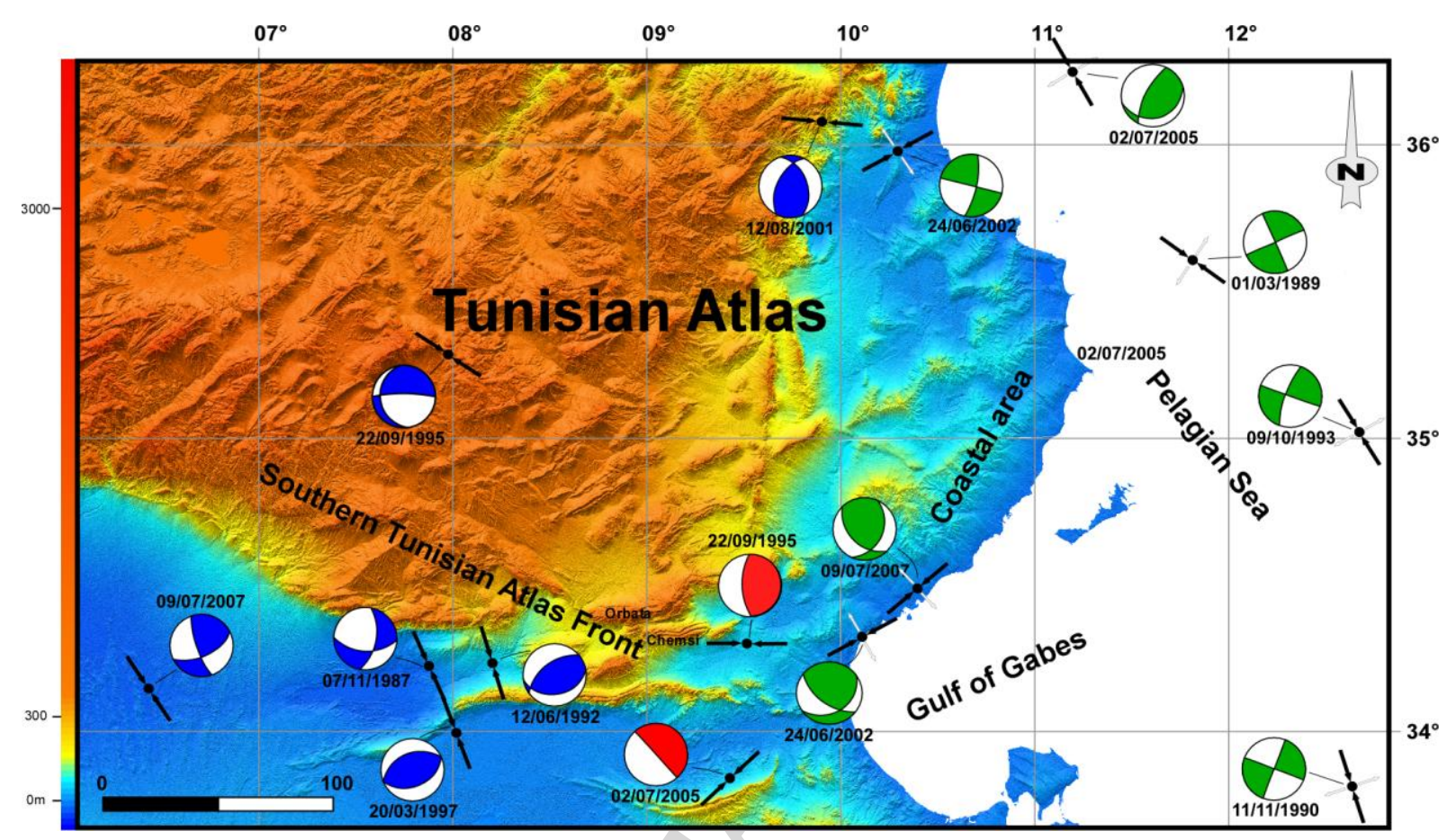

Figure 10 


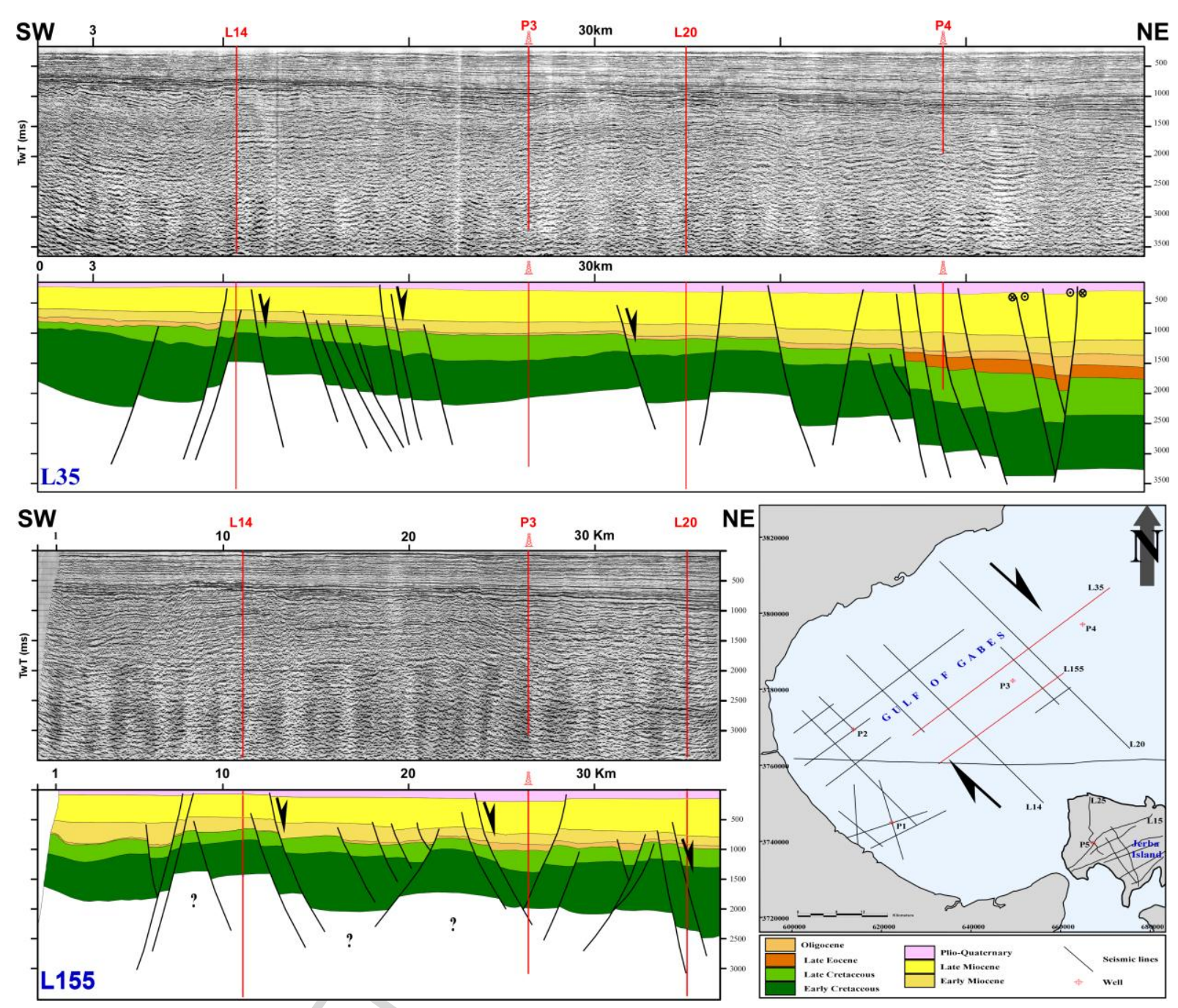

Figure 11 


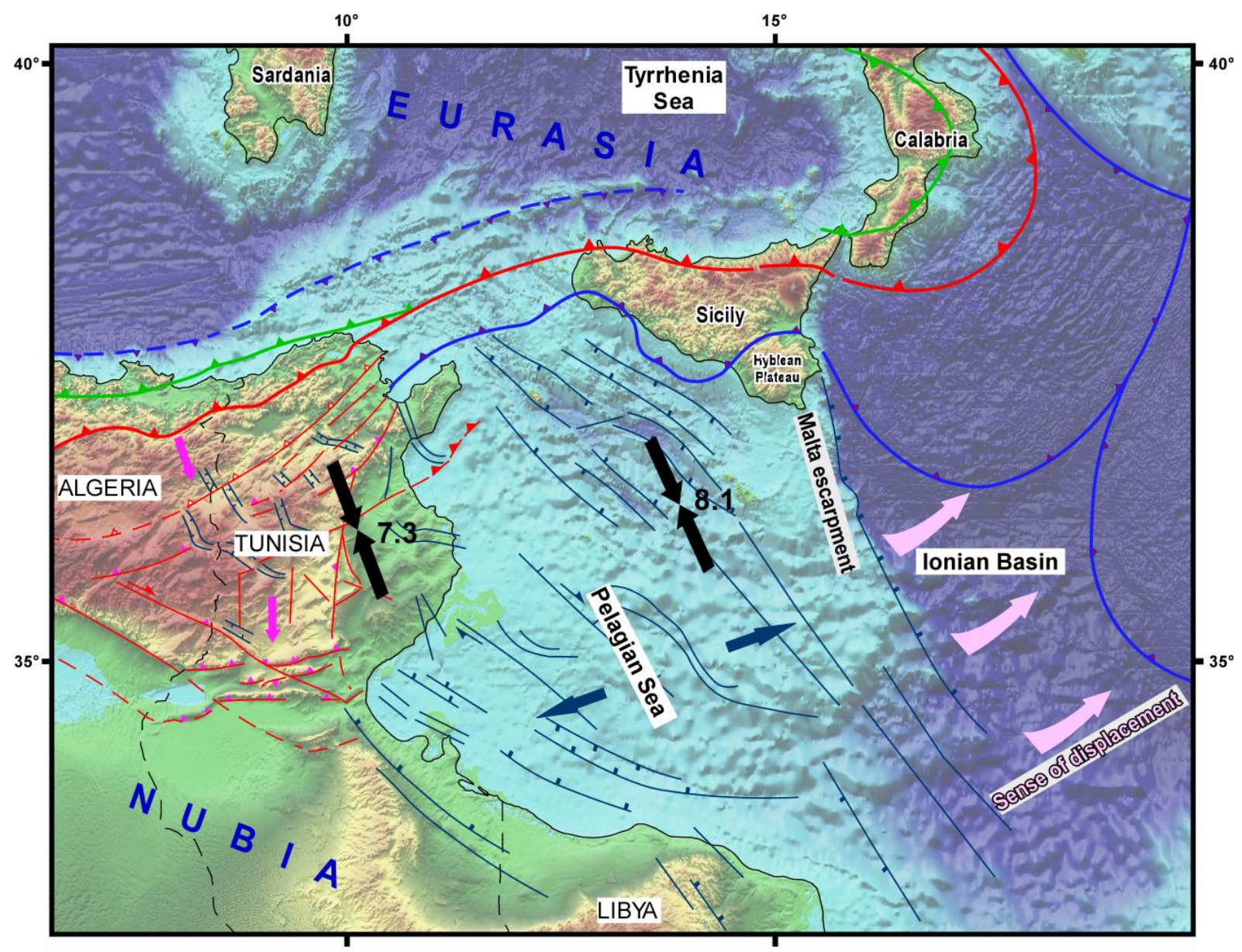

Kabylides-Peloritan-Calabrian
crystalline units Tellian front

Figure 12 
Table 1

\begin{tabular}{|c|c|c|c|c|c|c|c|c|c|c|c|c|c|c|c|c|c|c|c|}
\hline \multirow{3}{*}{ Site } & \multirow{3}{*}{$(X)$} & \multirow{3}{*}{ (Y) } & \multicolumn{7}{|c|}{ Paleostress } & \multicolumn{7}{|c|}{ Modern stress } & \multirow{3}{*}{$\begin{array}{l}\text { Lithol } \\
\text { ogy }\end{array}$} & \multirow{3}{*}{ Formation } & \multirow{3}{*}{$\begin{array}{c}\text { Refere } \\
\text { nces }\end{array}$} \\
\hline & & & \multicolumn{3}{|c|}{$\begin{array}{c}\text { Stress axis } \\
\text { (trend/plunge) }\end{array}$} & \multirow[t]{2}{*}{$\mathbf{R}$} & \multirow[t]{2}{*}{$\mathbf{N}$} & \multirow{2}{*}{$\mathbf{Q}$} & \multirow{2}{*}{$\begin{array}{l}\mathbf{R} \\
\mathbf{m}\end{array}$} & \multicolumn{3}{|c|}{$\begin{array}{c}\text { Stress axis } \\
\text { (trend/plunge) }\end{array}$} & \multirow[t]{2}{*}{$\mathbf{R}$} & \multirow[t]{2}{*}{$\mathbf{N}$} & \multirow[t]{2}{*}{$\mathbf{Q}$} & \multirow{2}{*}{$\begin{array}{l}R \\
m\end{array}$} & & & \\
\hline & & & $\sigma 1$ & $\sigma 2$ & $\sigma 3$ & & & & & $\sigma 1$ & $\sigma 2$ & $\sigma 3$ & & & & & & & \\
\hline $\mathrm{O} 24$ & $\begin{array}{l}531 \\
518\end{array}$ & $\begin{array}{c}3795 \\
030\end{array}$ & $\begin{array}{c}294 / \\
08\end{array}$ & $\begin{array}{l}196 \\
/ 45\end{array}$ & $\begin{array}{c}32 / \\
44\end{array}$ & $\begin{array}{l}0 . \\
3\end{array}$ & 6 & B & C & $\begin{array}{c}05 / \\
25\end{array}$ & $\begin{array}{c}98 / \\
06\end{array}$ & $\begin{array}{l}200 \\
/ 64\end{array}$ & $\begin{array}{l}0 . \\
9\end{array}$ & $\begin{array}{l}0 \\
6\end{array}$ & B & $\mathrm{C}$ & Cong & $\begin{array}{c}\text { Segui- } \\
\text { Quat-Terr }\end{array}$ & $1,2,3$ \\
\hline $\begin{array}{c}024 \\
Q\end{array}$ & $\begin{array}{l}531 \\
518 \\
\end{array}$ & $\begin{array}{c}3795 \\
030\end{array}$ & & & & & & & & $\begin{array}{c}02 / \\
7 \\
\end{array}$ & $\begin{array}{l}106 \\
/ 70 \\
\end{array}$ & $\begin{array}{l}268 \\
/ 18 \\
\end{array}$ & $\begin{array}{l}0 . \\
9 \\
\end{array}$ & $\begin{array}{l}0 \\
7\end{array}$ & B & C & Cong & Quat-Terr & $1,2,3$ \\
\hline $91 \mathrm{~B}$ & $\begin{array}{l}531 \\
471\end{array}$ & $\begin{array}{c}3794 \\
981\end{array}$ & $\begin{array}{c}342 / \\
08\end{array}$ & $\begin{array}{c}252 \\
/ 4\end{array}$ & $\begin{array}{c}83 / \\
85\end{array}$ & $\begin{array}{l}0 . \\
3\end{array}$ & $\begin{array}{l}1 \\
9\end{array}$ & A & C & - & - & - & - & - & - & - & Cong & Segui & $1,2,3$ \\
\hline $91 \mathrm{~A}$ & $\begin{array}{l}531 \\
409 \\
\end{array}$ & $\begin{array}{c}3794 \\
934 \\
\end{array}$ & $\begin{array}{c}166 / \\
07 \\
\end{array}$ & $\begin{array}{l}258 \\
/ 15 \\
\end{array}$ & $\begin{array}{c}53 / \\
73 \\
\end{array}$ & $\begin{array}{l}0 . \\
8 \\
\end{array}$ & $\begin{array}{l}1 \\
4 \\
\end{array}$ & $A$ & $\mathrm{C}$ & $\begin{array}{l}189 \\
102 \\
\end{array}$ & $\begin{array}{c}99 / \\
06 \\
\end{array}$ & $\begin{array}{l}301 \\
/ 83 \\
\end{array}$ & $\begin{array}{l}0 . \\
4 \\
\end{array}$ & $\begin{array}{l}0 \\
5 \\
\end{array}$ & A & $\mathrm{C}$ & Cong & $\begin{array}{c}\text { Segui- } \\
\text { Quat-Terr }\end{array}$ & $1,2,3$ \\
\hline $\begin{array}{c}91 A \\
Q \\
\end{array}$ & $\begin{array}{l}531 \\
409 \\
\end{array}$ & $\begin{array}{c}3794 \\
934 \\
\end{array}$ & & & & & & & & $\begin{array}{l}181 \\
/ 11 \\
\end{array}$ & $\begin{array}{l}295 \\
/ 64 \\
\end{array}$ & $\begin{array}{r}87 / \\
22 \\
\end{array}$ & $\begin{array}{l}0 . \\
7 \\
\end{array}$ & $\begin{array}{l}0 \\
8 \\
\end{array}$ & B & C & Cong & Quat-Terr & $1,2,3$ \\
\hline $\begin{array}{c}\text { S30 } \\
5 \\
\end{array}$ & $\begin{array}{l}529 \\
730 \\
\end{array}$ & $\begin{array}{c}3794 \\
720 \\
\end{array}$ & $\begin{array}{c}145 / \\
24 \\
\end{array}$ & $\begin{array}{c}237 \\
14 \\
\end{array}$ & $\begin{array}{l}337 \\
165 \\
\end{array}$ & $\begin{array}{l}0 . \\
9 \\
\end{array}$ & $\begin{array}{l}1 \\
4 \\
\end{array}$ & A & C & - & - & - & - & - & - & - & Cong & Segui & 2 \\
\hline 93 & $\begin{array}{l}528 \\
862 \\
\end{array}$ & $\begin{array}{c}3794 \\
109 \\
\end{array}$ & $\begin{array}{c}335 / \\
0.6 \\
\end{array}$ & $\begin{array}{c}65 / \\
21 \\
\end{array}$ & $\begin{array}{l}243 \\
169 \\
\end{array}$ & $\begin{array}{l}0 . \\
6 \\
\end{array}$ & $\begin{array}{l}1 \\
3 \\
\end{array}$ & B & $\mathrm{C}$ & - & - & - & - & - & - & - & Cong & Segui & 2 \\
\hline 92 & $\begin{array}{l}528 \\
879 \\
\end{array}$ & $\begin{array}{c}3793 \\
686 \\
\end{array}$ & $\begin{array}{c}315 / \\
11 \\
\end{array}$ & $\begin{array}{l}225 \\
102 \\
\end{array}$ & $\begin{array}{l}123 \\
/ 79 \\
\end{array}$ & $\begin{array}{l}0 . \\
4\end{array}$ & $\begin{array}{l}0 \\
6 \\
\end{array}$ & $A$ & $\mathrm{C}$ & - & - & - & - & - & - & - & Cong & Segui & 2 \\
\hline $\begin{array}{c}\text { S30 } \\
3\end{array}$ & $\begin{array}{l}523 \\
077 \\
\end{array}$ & $\begin{array}{c}3792 \\
667\end{array}$ & $\begin{array}{c}160 / \\
03\end{array}$ & $\begin{array}{l}251 \\
/ 18 \\
\end{array}$ & $\begin{array}{c}60 / \\
71 \\
\end{array}$ & $\begin{array}{l}0 . \\
6\end{array}$ & $\begin{array}{l}1 \\
5\end{array}$ & A & C & - & - & - & - & - & - & - & $\begin{array}{c}\text { Lime } \\
\mathrm{s}\end{array}$ & Up-Cret & 2 \\
\hline 11 & $\begin{array}{l}521 \\
283 \\
\end{array}$ & $\begin{array}{c}3792 \\
666 \\
\end{array}$ & $\begin{array}{c}316 / \\
27 \\
\end{array}$ & $\begin{array}{l}123 \\
/ 62 \\
\end{array}$ & $\begin{array}{l}223 \\
105 \\
\end{array}$ & $\begin{array}{l}0 . \\
8 \\
\end{array}$ & $\begin{array}{l}0 \\
8 \\
\end{array}$ & $A$ & $\mathrm{~S}$ & - & - & - & - & - & - & - & Cong & Segui & 2 \\
\hline 73 & $\begin{array}{l}524 \\
289 \\
\end{array}$ & $\begin{array}{c}3805 \\
072 \\
\end{array}$ & $\begin{array}{c}114 / \\
16 \\
\end{array}$ & $\begin{array}{c}20 / \\
12 \\
\end{array}$ & $\begin{array}{l}264 \\
/ 70 \\
\end{array}$ & $\begin{array}{l}0 . \\
9\end{array}$ & $\begin{array}{l}1 \\
2 \\
\end{array}$ & B & $\mathrm{C}$ & $\begin{array}{l}359 \\
/ 12 \\
\end{array}$ & $\begin{array}{l}103 \\
/ 48 \\
\end{array}$ & $\begin{array}{l}259 \\
/ 39 \\
\end{array}$ & $\begin{array}{l}0 . \\
9 \\
\end{array}$ & $\begin{array}{l}1 \\
0\end{array}$ & A & C & Cong & Segui & 2 \\
\hline 72 & $\begin{array}{l}524 \\
424\end{array}$ & $\begin{array}{c}3804 \\
899\end{array}$ & $\begin{array}{c}124 / \\
10\end{array}$ & $\begin{array}{l}218 \\
/ 24\end{array}$ & $\begin{array}{c}13 / \\
63\end{array}$ & $\begin{array}{l}0 . \\
3\end{array}$ & $\begin{array}{l}0 \\
6\end{array}$ & B & C & - & - & - & - & - & - & - & Cong & Segui & 1,2 \\
\hline 86 & $\begin{array}{l}525 \\
185 \\
\end{array}$ & $\begin{array}{c}3802 \\
740\end{array}$ & $\begin{array}{c}343 / \\
12 \\
\end{array}$ & $\begin{array}{l}191 \\
/ 76\end{array}$ & $\begin{array}{c}75 / \\
06 \\
\end{array}$ & $\begin{array}{l}0 . \\
9 \\
\end{array}$ & $\begin{array}{l}1 \\
6 \\
\end{array}$ & $A$ & $S$ & - & - & - & - & - & - & - & Cong & Segui & $1,2,3$ \\
\hline $\begin{array}{c}\mathrm{S} 28 \\
1 \\
\end{array}$ & $\begin{array}{l}522 \\
193 \\
\end{array}$ & $\begin{array}{c}3803 \\
726 \\
\end{array}$ & $\begin{array}{c}159 / \\
13\end{array}$ & $\begin{array}{c}64 / \\
20 \\
\end{array}$ & $\begin{array}{l}277 \\
166 \\
\end{array}$ & $\begin{array}{l}0 . \\
9 \\
\end{array}$ & $\begin{array}{l}0 \\
6 \\
\end{array}$ & $A$ & $\mathrm{C}$ & $\begin{array}{l}218 \\
/ 01 \\
\end{array}$ & $\begin{array}{l}308 \\
/ 12 \\
\end{array}$ & $\begin{array}{l}125 \\
/ 78 \\
\end{array}$ & $\begin{array}{l}0 . \\
6 \\
\end{array}$ & $\begin{array}{l}1 \\
7 \\
\end{array}$ & $\begin{array}{l}\mathrm{C} \\
\mathrm{F}\end{array}$ & $\mathrm{C}$ & Cong & $\begin{array}{c}\text { Segui- } \\
\text { Quat-Terr }\end{array}$ & 2,3 \\
\hline $\begin{array}{l}S 28 \\
1 Q\end{array}$ & $\begin{array}{l}522 \\
193\end{array}$ & $\begin{array}{c}3803 \\
726\end{array}$ & & & & & & & & $\begin{array}{l}200 \\
/ 10\end{array}$ & $\begin{array}{l}293 \\
/ 16\end{array}$ & $\begin{array}{l}71 / \\
79\end{array}$ & $\begin{array}{l}0 . \\
3\end{array}$ & $\begin{array}{l}0 \\
6\end{array}$ & B & C & Cong & Quat-Terr & 2,3 \\
\hline $\begin{array}{c}\text { S28 } \\
2 \\
\end{array}$ & $\begin{array}{l}522 \\
220 \\
\end{array}$ & $\begin{array}{c}3803 \\
890 \\
\end{array}$ & - & - & - & - & - & - & - & $\begin{array}{l}357 \\
/ 01 \\
\end{array}$ & $\begin{array}{l}267 \\
/ 18 \\
\end{array}$ & $\begin{array}{c}91 / \\
72 \\
\end{array}$ & $\begin{array}{l}0 . \\
5 \\
\end{array}$ & $\begin{array}{l}0 \\
7 \\
\end{array}$ & $\begin{array}{l}\mathrm{C} \\
\mathrm{F}\end{array}$ & C & Cong & Segui & 2,3 \\
\hline 101 & $\begin{array}{l}514 \\
642 \\
\end{array}$ & $\begin{array}{c}3801 \\
674 \\
\end{array}$ & $\begin{array}{c}141 / \\
11 \\
\end{array}$ & $\begin{array}{c}46 / \\
26 \\
\end{array}$ & $\begin{array}{l}252 \\
162 \\
\end{array}$ & 7 & $\begin{array}{l}0 \\
8 \\
\end{array}$ & $A$ & $\mathrm{C}$ & $\begin{array}{l}176 \\
/ 10 \\
\end{array}$ & $\begin{array}{c}27 / \\
78 \\
\end{array}$ & $\begin{array}{l}267 \\
/ 06 \\
\end{array}$ & $\begin{array}{l}0 . \\
5 \\
\end{array}$ & $\begin{array}{l}0 \\
6 \\
\end{array}$ & A & $S$ & Cong & Segui & 2,3 \\
\hline 012 & $\begin{array}{l}582 \\
872\end{array}$ & $\begin{array}{c}3798 \\
312\end{array}$ & $\begin{array}{c}122 / \\
06\end{array}$ & $\begin{array}{c}27 / \\
36\end{array}$ & $\begin{array}{l}219 \\
/ 54\end{array}$ & $\begin{array}{c}0 . \\
6\end{array}$ & $\begin{array}{l}1 \\
2\end{array}$ & $A$ & C & - & - & - & - & - & - & - & Cong & Segui & 2,3 \\
\hline 011 & $\begin{array}{l}512 \\
893\end{array}$ & $\begin{array}{c}3798 \\
210\end{array}$ & $\begin{array}{c}144 / \\
07\end{array}$ & $\begin{array}{l}234 \\
/ 07\end{array}$ & $\begin{array}{c}11 / \\
79\end{array}$ & $\begin{array}{l}0 . \\
7\end{array}$ & $\begin{array}{l}1 \\
0\end{array}$ & B & C & - & - & - & - & - & - & - & $\begin{array}{c}\text { Lime } \\
\mathrm{s}\end{array}$ & $\begin{array}{c}\text { Up- } \\
\text { Cret/Tor- } \\
\text { Plio }\end{array}$ & 2,3 \\
\hline 013 & $\begin{array}{l}513 \\
449 \\
\end{array}$ & $\begin{array}{c}3797 \\
709\end{array}$ & $\begin{array}{c}332 / \\
01 \\
\end{array}$ & $\begin{array}{c}62 / \\
05\end{array}$ & $\begin{array}{l}240 \\
/ 84 \\
\end{array}$ & 0. & $\begin{array}{l}0 \\
6 \\
\end{array}$ & $\begin{array}{l}\mathrm{C} \\
\mathrm{F}\end{array}$ & C & - & - & - & - & - & - & - & Cong & Segui & 2 \\
\hline O32 & $\begin{array}{l}500 \\
661 \\
\end{array}$ & $\begin{array}{c}3794 \\
655 \\
\end{array}$ & - & - & - & - & - & - & - & $\begin{array}{c}05 / \\
08 \\
\end{array}$ & $\begin{array}{l}270 \\
133 \\
\end{array}$ & $\begin{array}{l}107 \\
/ 56 \\
\end{array}$ & $\begin{array}{l}0 . \\
8 \\
\end{array}$ & $\begin{array}{l}1 \\
3 \\
\end{array}$ & B & $\mathrm{C}$ & Cong & Segui & 2 \\
\hline O33 & $\begin{array}{l}500 \\
308 \\
\end{array}$ & $\begin{array}{c}3795 \\
388\end{array}$ & $\begin{array}{c}322 / \\
06\end{array}$ & $\begin{array}{l}232 \\
101 \\
\end{array}$ & $\begin{array}{l}130 \\
/ 84 \\
\end{array}$ & $\begin{array}{l}0 . \\
9 \\
\end{array}$ & $\begin{array}{l}0 \\
8 \\
\end{array}$ & A & C & - & - & - & - & - & - & - & Cong & Segui & 2 \\
\hline $\begin{array}{l}\text { S29 } \\
2^{*}\end{array}$ & $\begin{array}{l}547 \\
571 \\
\end{array}$ & $\begin{array}{c}3799 \\
708 \\
\end{array}$ & - & - & - & - & - & - & - & $\begin{array}{l}176 \\
103 \\
\end{array}$ & $\begin{array}{c}85 / \\
05 \\
\end{array}$ & $\begin{array}{l}269 \\
190 \\
\end{array}$ & $\begin{array}{l}0 . \\
9 \\
\end{array}$ & $\begin{array}{l}0 \\
5 \\
\end{array}$ & A & C & Cong & $\begin{array}{c}\text { Up- } \\
\text { Cret/Quat }\end{array}$ & 2 \\
\hline A31 & $\begin{array}{l}582 \\
765\end{array}$ & $\begin{array}{c}3762 \\
863\end{array}$ & $\begin{array}{c}334 / \\
06\end{array}$ & $\begin{array}{l}236 \\
/ 52\end{array}$ & $\begin{array}{c}69 / \\
37\end{array}$ & $\begin{array}{l}0 . \\
4\end{array}$ & $\begin{array}{l}1 \\
5\end{array}$ & $A$ & $\mathrm{~S}$ & $\begin{array}{l}25 / \\
82\end{array}$ & $\begin{array}{l}161 \\
/ 06\end{array}$ & $\begin{array}{l}251 \\
/ 05\end{array}$ & $\begin{array}{l}0 . \\
8\end{array}$ & $\begin{array}{l}0 \\
9\end{array}$ & A & $E$ & $\underset{s}{\text { Lime }}$ & Eoc/Quat & 4 \\
\hline
\end{tabular}




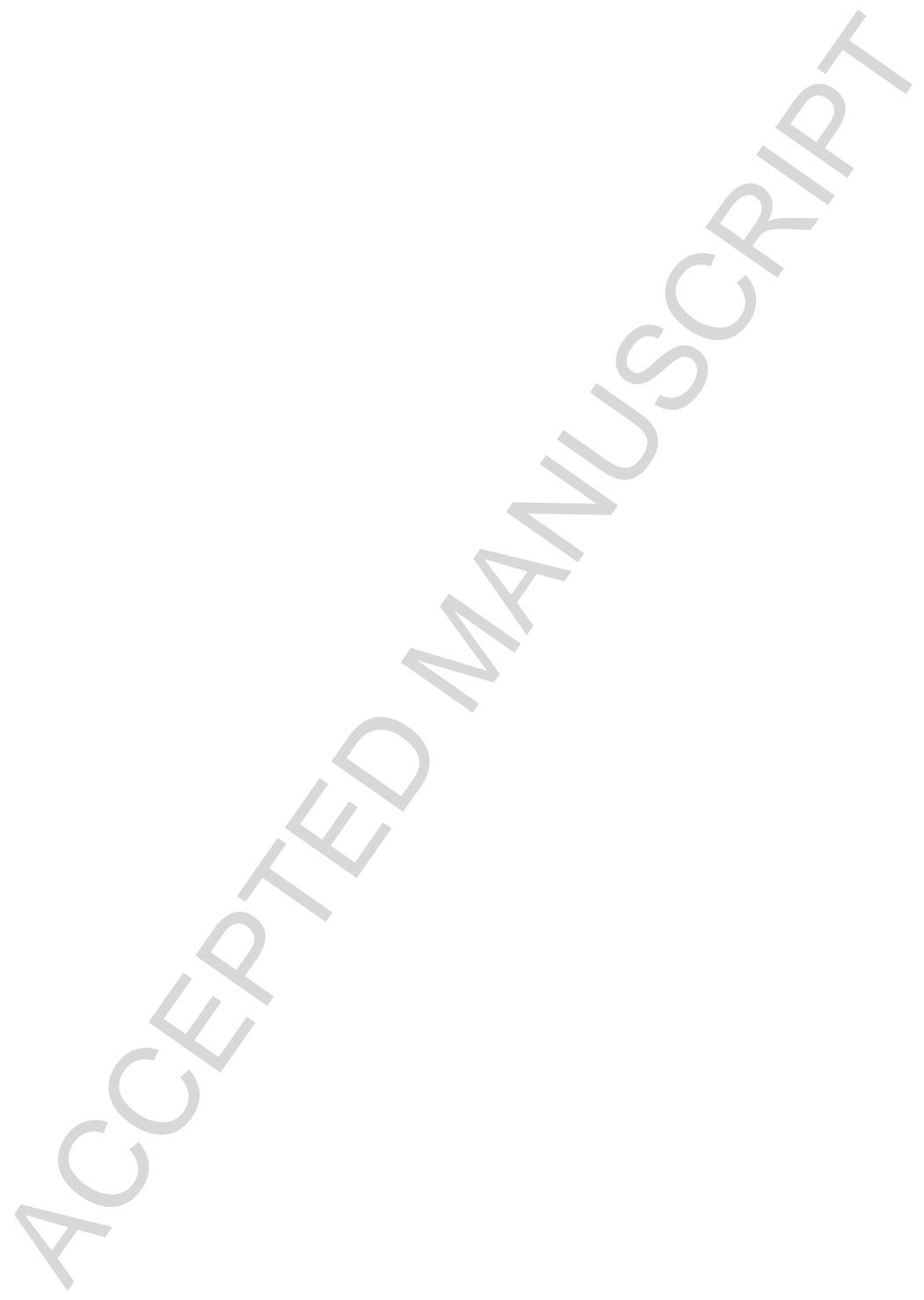


Table 2

\begin{tabular}{|c|c|c|c|c|c|c|c|c|c|c|c|c|}
\hline \multirow[b]{2}{*}{$\mathbf{N}$} & \multirow{2}{*}{$\begin{array}{c}\text { DATE } \\
\text { (ddmmyyyy) }\end{array}$} & \multirow{2}{*}{$\begin{array}{l}\text { LAT. } \\
\text { ('N) }\end{array}$} & \multirow{2}{*}{$\begin{array}{l}\text { Long. } \\
\left({ }^{\circ} \mathrm{E}\right)\end{array}$} & \multirow{2}{*}{$\begin{array}{l}M \\
\mathbf{w}\end{array}$} & \multicolumn{3}{|c|}{ Nodal plane I } & \multicolumn{3}{|c|}{ Nodal plane II } & \multirow{2}{*}{$\begin{array}{l}\text { Depth } \\
(\mathrm{Km})\end{array}$} & \multirow{2}{*}{$\begin{array}{c}\text { Sourc } \\
\text { e }\end{array}$} \\
\hline & & & & & $\begin{array}{c}\text { Azimut } \\
\mathrm{h}\end{array}$ & $\begin{array}{l}\mathrm{Di} \\
\mathrm{p}\end{array}$ & $\begin{array}{c}\text { Rak } \\
\text { e }\end{array}$ & $\begin{array}{c}\text { Azimut } \\
\mathrm{h}\end{array}$ & $\begin{array}{l}\mathrm{Di} \\
\mathrm{p}\end{array}$ & $\begin{array}{c}\text { Rak } \\
\text { e }\end{array}$ & & \\
\hline $\begin{array}{l}0 \\
1\end{array}$ & 01031989 & 35.79 & 11.80 & 5.0 & 247 & 90 & 180 & 337 & 90 & 0 & 15 & CMT \\
\hline $\begin{array}{l}0 \\
2\end{array}$ & 07111989 & 34.15 & 8.15 & 4.4 & 10 & 70 & 22 & 93 & 66 & 20 & 8 & $D \& H$ \\
\hline $\begin{array}{l}0 \\
3\end{array}$ & 11111990 & 33.73 & 12.28 & 4.9 & 291 & 90 & $\begin{array}{c}- \\
180\end{array}$ & 21 & 90 & 0 & 15 & CMT \\
\hline $\begin{array}{l}0 \\
4\end{array}$ & 12061992 & 34.21 & 08.44 & 5.2 & 82 & 36 & 114 & 233 & 57 & 73 & 15 & CMT \\
\hline $\begin{array}{l}0 \\
5\end{array}$ & 09101993 & 34.99 & 12.44 & 5.0 & 200 & 78 & 1 & 110 & 89 & 168 & 26.10 & CMT \\
\hline $\begin{array}{l}0 \\
6\end{array}$ & 22091995 & 35.31 & 08.23 & 5.3 & 173 & 41 & -8 & 270 & 84 & $\begin{array}{c}- \\
130\end{array}$ & 15 & HRV \\
\hline $\begin{array}{l}0 \\
7\end{array}$ & 22091995 & 34.28 & 09.58 & 3.7 & 178 & 75 & 83 & 22 & 15 & 81 & 10 & INMT \\
\hline $\begin{array}{l}0 \\
8\end{array}$ & 20031997 & 33.96 & 08.28 & 5.2 & - & - & - & - & - & - & 10 & INMT \\
\hline $\begin{array}{l}0 \\
9\end{array}$ & 12082001 & 35.92 & 09.81 & 4.5 & 67 & 72 & $\begin{array}{c}- \\
177\end{array}$ & 336 & 87 & -18 & 15 & INGV \\
\hline $\begin{array}{l}1 \\
0\end{array}$ & 24062002 & 36.03 & 10.29 & 5.2 & 28 & 28 & 128 & 158 & 54 & 56 & 15 & HRV \\
\hline $\begin{array}{l}1 \\
1\end{array}$ & 24062002 & 34.30 & 10.27 & 3.5 & 56 & 50 & -37 & 128 & 70 & -41 & ? & INMT \\
\hline $\begin{array}{l}1 \\
2\end{array}$ & 07022005 & 36.30 & 11.10 & 4.9 & 79 & 21 & 136 & 211 & 75 & 74 & 15 & INGV \\
\hline $\begin{array}{l}1 \\
3\end{array}$ & 07022005 & 33.80 & 09.50 & 5.2 & 75 & 2 & $\begin{array}{c}- \\
153 \\
\end{array}$ & 318 & 89 & 88 & 10 & ETHZ \\
\hline $\begin{array}{l}1 \\
4 \\
\end{array}$ & 09072007 & 34.47 & 10.35 & 3.5 & 24 & 54 & -63 & 136 & 60 & 65 & ? & INMT \\
\hline $\begin{array}{l}1 \\
5\end{array}$ & 09072007 & 34.10 & 06.89 & 4.8 & 64 & 62 & 165 & 161 & 76 & 29 & 16 & HRV \\
\hline
\end{tabular}


Highlights

Analyses of Fault kinematics and Seismic data are presented. Previous published geodynamic data of the western Mediterranean are used. Recent spatial and temporal changes in the stress regime are highlighted. 